\title{
Qual era o Projeto Econômico Varguista?`
}

\author{
Pedro Paulo Zahluth Bastos ${ }^{\star}$
}

\begin{abstract}
Resumo
O artigo discute a formação do projeto econômico do segundo governo de Getúlio Vargas a partir do Estado Novo. Argumenta-se que o projeto enquadrava-se na ideologia nacional-desenvolvimentista que Vargas defendia pelo menos desde a década de 1930, porém tendo sido antecipado pelo detalhamento do conjunto integrado de políticas praticado na década de 1950, durante a Segunda Guerra Mundial e, depois, defendido no período da reação liberal; proposto na campanha presidencial de 1950, e fiscalizado durante o segundo governo.
\end{abstract}

\section{Palavras-Chave}

Vargas, trabalhismo, nacional-desenvolvimentismo, liberalismo

\section{Which was Vargas ' Economic Program?}

\begin{abstract}
The paper studies the formation of the development strategy in Getúlio Vargas' second term, since the Estado Novo's regime. The argument is that this strategy was embedded in the national-developmentalist ideology which Vargas embraced at least since the 1930', but it was anticipated in the coherent set of policies executed in the 1950's during the Second World War, and advocated in the postwar period of neo-liberal predominance and during the electoral campaign of 1950, before undertaken in Vargas' second term.
\end{abstract}

\section{Keywords}

Vargas, labourism, national-developmentalism, liberalism

\section{JEL Classification}

G28, O16, O19

+ Artigo recebido em maio de 2009 e aceito para publicação em dezembro de 2010.

Agradeço a Pedro Dutra Fonseca (UFRGS) e Carlos Pinkusfeld Bastos (UFRJ) pelos comentários feitos a versões anteriores do artigo, apresentadas no XXXVII Encontro Nacional de Economia - ANPEC, Foz do Iguaçu, 2009, e no XIV Encontro Nacional de Economia Política - SEP, São Paulo, 2009. A pesquisa que levou ao artigo envolveu a consulta a arquivos organizados pelo U.S. National Archives (listados pela sigla NA, e classificados por data na forma mm-ddaa), e pelo Centro de Pesquisa e Documentação de História Contemporânea do Brasil (CPDOC-FGV), classificados por data invertida (aa/mm/dd), e listados pelas siglas: GV - Getúlio Vargas; OA - Oswaldo Aranha; SC - Souza Costa. Parte dos resultados do artigo foram apresentados na tese de doutorado não publicada do autor (BASTOS, 2001), financiada pelo CNPq e pela FAPESP; agradeço a orientação de Luiz Gonzaga Belluzzo, e as sugestões de Carlos Alonso Barbosa de Oliveira, Paul Singer, Reginaldo Moraes, e Wilson Cano, eximindo-os dos erros remanescentes.

* Professor do Instituto de Economia - UNICAMP, e presidente da Associação Brasileira de pesquisadores em História Econômica (ABPHE) - Endereço para contato: Rua Pitágoras, 353 - Cidade Universitária "Professor Zeferino Vaz" - CEP 13083-970 - Campinas - São Paulo Email: ppzbastos@gmail.com 


\section{Introducão}

O artigo entra na controvérsia sobre o projeto do segundo governo Getúlio Vargas, apresentando documento e discursos que comprovam ter sido este projeto apresentado pelo próprio estadista. Embora se considere, aqui, que a ação política de Vargas se enquadrava, em linhas gerais, na ideologia nacional-desenvolvimentista pelo menos desde a década de 1930, argumenta-se que os contornos precisos de um planejamento de governo envolveram o detalhamento de um conjunto coerente de políticas que, pela primeira vez, foi antecipado no final do Estado Novo. A seguir, na oposição ao governo Dutra, estas políticas foram apresentadas explicitamente como um legado a ser valorizado contra a virada liberal que o país experimentava, e como um programa a ser executado para recuperar o desenvolvimento social e econômico perdido. A elaboração deste programa foi aperfeiçoada em pronunciamentos lidos por Vargas no Congresso Nacional e na campanha presidencial. O comprometimento do presidente com este projeto pode ser atestado pela reiteração integral de seus temas na Mensagem Anual, apresentando iniciativas executivas e Projetos de Lei ao Congresso Nacional, em 1951, e pela nomeação de uma equipe econômica cujas tarefas foram estipuladas programaticamente. Embora não seja possível afirmar que o programa tenha sido implementado pela equipe com correspondência integral, pode-se afirmar que o presidente procurou fiscalizar as políticas para corrigir desvios maiores ou menores, recorrendo aos mesmos fiscais que contribuíram, sob sua direção e finalização, para escrever e publicar o programa nacional-desenvolvimentista.

Ao defender que o projeto econômico do segundo governo Vargas era coerente, o artigo dialoga criticamente com visões que sugerem a hipótese de ambiguidade, incoerência e mesmo de indecisão de Vargas entre diferentes objetivos (para maior detalhamento, ver BASTOS, 2005). A versão mais rica desta vertente interpretativa seja de M.C. D’Araújo (1982), que explica a ambiguidade pela necessidade de conciliar interesses diferentes que, na prática, eram inconciliáveis e mutuamente incoerentes. De um lado, Vargas precisaria responder às exigências do nacionalpopulismo e do desenvolvimentismo, assegurando popularidade junto às camadas urbanas e respondendo a seus compromissos nacionalistas históricos. De outro lado, em função de acordos que viabilizaram sua candidatura, posse e governabilidade junto ao Congresso, compusera-se politicamente com setores mais conservadores e/ou alinhados com interesses econômicos e políticos norte-americanos. Esta incoerência geraria impasses e contradições na ação do governo, e seria fonte permanente de instabilidade política à medida que induzia "a manifestação de temores e suspeitas quanto à disposição do governo em ceder a qualquer das partes envolvidas nas negociações... (e o governo) nessa expectativa da grande conciliação acaba por 
perder-se e isolar-se num emaranhado de compromissos que não ganham a confiança das outras partes interessadas" (p. 134).

Parece haver poucas dúvidas de que a crise do governo foi marcada por pressões dos mais diferentes atores políticos (à esquerda e à direita) e, da parte do governo, por propostas e decisões contraditórias, visando recuperar o prestígio junto a algum grupo de interesses específicos e acabando por afastar ainda mais algum grupo concorrente (M.C. D’ARAÚJO, 1982, pp. 113-126). Este modelo interpretativo é indubitavelmente frutuoso na análise da crise política do último ano do governo. Para D'Araújo, ademais, esta crise final não seria fortuita, estando prenhe na maneira como o governo se constituiu desde o primeiro gabinete ministerial, buscando equilibrar e conciliar interesses inconciliáveis. Assim, a autora rejeita outras formas de destacar a ambiguidade do governo que apelariam para a existência de diferentes "fases" ao longo do mandato (normalmente tendo como marco a reforma ministerial de meados de 1953 ou o reajuste salarial de 1954), em que cada uma de duas das vertentes opostas possíveis (direita x esquerda; cooperação internacional $\mathrm{x}$ nacionalismo; ortodoxia $\mathrm{x}$ populismo; estabilidade monetária $\mathrm{x}$ desenvolvimento) seria predominante. Para ela, Vargas sempre foi e teria permanecido ambíguo e indefinido até o fim. ${ }^{1}$

Na área econômica, desde o início do governo, a "coexistência ambígua" seria marcada, por um lado, pela formação da Assessoria Econômica, portadora de "uma linha de ação que se identifica com princípios nacionalistas e que imprime ao governo um caráter nacional-desenvolvimentista"; por sua vez, os ministérios da Fazenda e do Exterior e seu instrumento comum de ação, a CMBEU, estabeleceriam uma "linha que procura abertamente adequar os interesses brasileiros aos dos Estados Unidos” (M.C. D’ARAÚJO, 1982, p. 132). A autora não deixa muito claro qual seria o programa de ação econômico que o presidente queria executar, mas à luz de um comentário que precede a menção da presença de Horácio Lafer, João Neves e da CMBEU no governo ("assim como foi oferecida à UDN uma participação significativa, o governo preocupa-se também em representar os interesses econômicos que se contrapunham, inclusive, a seu programa de desenvolvimento"), pode-se inferir que seu programa de desenvolvimento foi elaborado com a Assessoria, e que estaria representado, sobretudo, na Mensagem Presidencial ao Congresso para abertura das seções de 1951.

1 Em suas palavras: "Não se pode falar em duas fases distintas do governo e, conseqüentemente, numa 'virada' de orientações (como) responsável pela situação de crise que impediu o término do mandato do presidente." (p. 160). O alvo da crítica é T. Skidmore (1967), que popularizou a noção de uma "virada política" no governo. No entanto, embora Skidmore tenha identificado uma "virada" para a esquerda no último ano de governo, ele considerava que, desde o início do governo, "a maneira de Vargas atacar essas questões (econômicas) era ambivalente...Em termos políticos, o problema de Vargas era manter o delicado equilíbrio entre ortodoxia e nacionalismo na política econômica." (pp. 124 e 132-133). 
O problema desta análise está, em parte, em encontrar o lugar do Ministério da Fazenda em um projeto que parece definir-se pela Assessoria Econômica: Lafer parece se contrapor ao projeto de desenvolvimento, reduzindo-se no limite a mero representante conservador de interesses locais alinhados a interesses econômicos e políticos estadunidenses. Em termos gerais, uma carência que compartilha com algumas interpretações que enfatizam a existência de ambiguidades no governo é que não procura distinguir, de início, se estas ambiguidades teriam resultado, seja 1) da incapacidade da cúpula executiva ao coordenar, na prática, as iniciativas díspares dos diferentes setores do governo para implementar um projeto unificado que, em si mesmo, era coerente enquanto ideia; 2) da ausência, de antemão, de uma idealização ou proposição clara quanto ao projeto que unificaria a ação do governo (a não ser, talvez, o projeto a decidir não definir-se), criando portanto uma indefinição quanto ao modo de articular e hierarquizar setores com diferentes visões de política e conferindo-lhes, implicitamente, excessiva autonomia para buscar objetivos díspares; ou, ainda, 3) de um pouco de ambos, um pouco de indefinição inicial e um pouco de falta de coordenação central posterior.

Uma maneira mais fácil de responder à questão é evadir-se dela: imaginar de antemão que não devam sequer existir indícios suficientes para determinar se a presidência dispunha de algum projeto que vinculasse as ações dos diferentes membros da equipe, ou que este projeto tenha sido coerentemente transmitido à equipe que o executaria. Neste caso, restaria constatar a presumida ambiguidade prática entre seus membros: não apenas entre a Assessoria Econômica e o Ministério, mas entre a gestão de Ricardo Jafet no Banco do Brasil e a de Horácio Lafer na Fazenda. Um corolário possível desta atitude seria sugerir ou que Vargas era irracional, passando a governar sem projeto de governo algum, ou que sua racionalidade estava em formar compromissos e distribuir cargos para apaziguar rivais políticos, com o único projeto de preservar-se em seu próprio cargo.

O objetivo do artigo é defender que nenhuma das possibilidades é convincente, pois há fortes indícios de que Vargas apresentou um programa econômico coerente para seu segundo governo, e procurou fiscalizar sua implementação, sem necessariamente assegurar, com isto, seu sucesso.

O primeiro item, a seguir, discute algumas interpretações sobre o projeto varguista, com o objetivo de apresentar a proposta do artigo à luz das contribuições características do "estado das artes", nem sempre de modo complementar, pois que às vezes contraditório. Ainda, o item aborda o modo como o projeto do segundo governo varguista foi antecipado pela formação gradual de um conjunto integrado de políticas anunciadas e/ou executadas no final do Estado Novo. O segundo item apresenta o detalhamento do programa até 1951. O terceiro desloca a interpretação da crise do 
projeto econômico para questões de financiamento, ao invés de incoerência política. O último item está reservado para considerações finais.

\section{O Projeto Nacional-Desenvolvimentista em Primeira Versão}

A memória histórica do segundo governo Vargas esteve muito preocupada em explicar sua crise. O que entrou em crise neste governo? Como o desenvolvimento econômico e social do país seria afetado? De certo modo, esta era também a preocupação da carta-testamento de Vargas. Segundo ela, o presidente suicida sacrificara-se como um mártir contra os inimigos que bloqueavam o desenvolvimento nacional-popular: trustes e cartéis, filiais estrangeiras, os Estados Unidos, as oligarquias locais e camadas médias conservadoras, que rejeitavam a colaboração necessária, seja para financiar o desenvolvimento nacional, seja para melhorar a vida dos trabalhadores pobres.

As interpretações acadêmicas do governo e sua crise não poderiam deixar de reagir à própria versão de Vargas, para referendá-la ou criticá-la. Alguns autores vinculados à esquerda política referendaram a interpretação de Vargas: Octávio Ianni, por exemplo, considera que até 1954:

"...é total o antagonismo entre os que desejam o desenvolvimento internacionalizado (ou associado com organizações externas) e os que pretendem acelerar o desenvolvimento econômico independente. É a época em que se impunha o aprofundamento das rupturas com os setores externos e com a sociedade tradicional, se se desejava entrar em novo estágio de aplicação do modelo getuliano. $\mathrm{O}$ suicídio de Vargas revela a vitória daqueles que queriam reformular e aprofundar as relações com o capitalismo internacional". 2

Se é verdade que, como afirma Ianni, Vargas era nacional-desenvolvimentista, ou seja, relacionava o interesse nacional ao desenvolvimento - ativado pela vontade política concentrada no Estado - a novas atividades econômicas, particularmente industriais (ver também FONSECA, 2005; BASTOS, 2006), não parece adequado identificar o nacionalismo de Vargas, ao longo de sua ação política, a formas particulares de intervenção estatal e de associação com o capital estrangeiro: ele não era xenófobo nem "entreguista”, mas sim flexível, pragmático e politicamente realista.

2 Ianni, 1968, p. 68. Com algumas diferenças, esta também é a interpretação de Nelson Werneck Sodré (1967; 1997). Segundo Pedro Fonseca $(2004 ; 2005)$, as raízes do projeto varguista se firmaram em 1928, quando Vargas fez discursos e tomou decisões como presidente do Rio Grande do Sul, que superavam restrições colocadas pelo ideário positivista à intervenção estatal, particularmente no campo do déficit público e do crédito dirigido pelo Estado. 
Mesmo no segundo governo, Vargas não deixou de buscar um desenvolvimento "associado com organizações externas", pois continuava carecendo contornar a escassez de reservas cambiais e obstáculos que adversários conservadores colocavam à centralização de recursos locais. Parece mais rigoroso afirmar que o objetivo de Vargas não era rejeitar a associação externa, mas lutar por termos de associação que atendessem a finalidades nacional-desenvolvimentistas, em barganhas que maximizassem interesses nacionais, em circunstâncias econômicas e políticas restritivas (FONSECA, 1987; BASTOS, 2006).

No pólo oposto de Ianni e Sodré, outros autores rejeitam não apenas que o segundo governo tivesse como alvo um desenvolvimento econômico independente, mas também que tivesse sequer um projeto coerente de industrialização pesada do país. Para Carlos Lessa \& José Luiz Fiori (1984), os investimentos planejados nos ramos básicos (sobretudo energia elétrica, transporte, siderurgia e petróleo) tinham natureza meramente reativa à percepção de pontos de estrangulamento setorial, que surgiram à medida que o processo de industrialização se expandia espontaneamente nos ramos de bens finais. Segundo os autores, por serem meramente parciais e reativos, os investimentos não teriam relação com qualquer projeto mais geral de desenvolvimento do país.

Esta conclusão parece inteiramente convincente, ao exagerar a natureza reativa e obrigatória, quase espontânea, dos projetos governamentais nos ramos básicos, e subestimar a importância que teriam, se executados, para superar o estágio de industrialização restringida característico do período. Dada a sua escala produtiva e financeira, seus requisitos de insumos e seu longo tempo de maturação, esses projetos não poderiam ser realizados isoladamente, de modo parcial e reativo, sem previsão de seus impactos interindustriais e sem mudanças institucionais significativas. De fato, os projetos envolviam encadeamentos de demanda, para frente e para trás das cadeias produtivas, que exigiam um planejamento integrado de diferentes setores, nos quais se deveria estimar uma ampliação da oferta além do ritmo de crescimento da demanda prévia, para acomodar as novas demandas geradas pela própria criação dos novos empreendimentos. Isto exigia criar novas instituições de controle e assessorias para formulação e acompanhamento de projetos, novos fundos fiscais e financeiros, e mesmo novas empresas estatais em ramos tradicionalmente explorados por concessionárias estrangeiras. Esta tarefa era custosa financeira e politicamente, além de envolver uma vontade política nada trivial e automática. Não é preciso se alongar sobre a experiência de outros países da região para mostrar que, diante de estrangulamentos setoriais e cambiais semelhantes, não "reagiram" como Vargas. Mesmo no Brasil, Dutra e Jânio Quadros tinham uma postura no mínimo ambígua em relação ao planejamento público e, sobretudo, ao investimento estatal. Dizer que o planejamento era imposto pela emergência de estrangulamentos envolve algum 
economicismo, ou seja, desconsidera que era uma escolha política como outras, enraizada em um conjunto de possibilidades abertas historicamente (cf. DRAIBE, 1985). Ademais, o desenvolvimento industrial não era visto apenas como um fato econômico: desde os primeiros anos da década de 1930 (antes que estrangulamentos básicos fossem pressionados pelo crescimento industrial "espontâneo"), Vargas considerava que o radicalismo político de massas seria um resultado inevitável de uma postura governamental que deixasse a estrutura econômica decadente (legitimada pela noção de vocação agrária do Brasil) "à própria sorte”, deixando também milhares de trabalhadores famintos fora do mercado de trabalho. Era preciso reformar o capitalismo e a rede de proteção social antes que o povo fizesse a revolução.

É verdade, porém, que os estrangulamentos na oferta de energia e insumos básicos indicavam concretamente o caminho que deveria ser seguido para retirar o processo de industrialização de sua natureza restringida. $\mathrm{O}$ conceito de industrialização restringida foi proposto por Tavares (1974) e Mello (1975), a fim de caracterizar a dinâmica contraditória de um padrão de industrialização que tendia a esgotar-se sem decisiva intervenção estatal. Desde 1933, a recuperação econômica brasileira diante da crise internacional se fazia em bases qualitativamente novas, estimulada pela expansão e diversificação industrial e urbana, mais do que por investimentos em ramos exportadores primário, secundário e terciário correspondentes. O movimento de expansão/diversificação, porém, deparava-se com limites, pois não induzia investimentos em serviços de infraestrutura e ramos industriais básicos "pesados" (associados às inovações técnicas da Segunda Revolução e seus desdobramentos) necessários pela expansão industrial. Essa industrialização restringida concentravase em itens de bens finais e alguns insumos e bens de capital mais "leves", cujos investimentos tinham requisitos de financiamento, tecnologia e escala de produção menores e adequados aos limites do mercado brasileiro, da capacidade de financiamento e da base tecnológica das empresas brasileiras. Filiais estrangeiras também resistiam a ampliar a oferta de energia elétrica, material de transporte, insumos pesados e seus respectivos ramos de bens de capital, seja por motivos externos (contração dos investimentos externos entre a Grande Depressão e a Segunda Guerra, atração do IDE estadunidense para a recuperação européia no pós-guerra), ou internos (incerteza de mercado, de fornecimento de insumos e de reservas cambiais para importações e remessas de lucros). Com isto, a expansão dependia de oportunidades de diversificação "fácil" que tendiam a se esgotar, bem como da frágil capacidade de importar propiciada pelas exportações tradicionais e créditos comerciais.

É claro que os estrangulamentos crescentes de energia, insumos básicos e reservas cambiais não passariam despercebidos por alguém que, como Vargas, era adepto do nacional-desenvolvimentismo: desenvolver economicamente a nação dependia, com urgência crescente, da redução da dependência de insumos importados. 
Mas as iniciativas estratégicas, visando desenvolver ramos básicos, não precisaram esperar e reagir ao aprofundamento das restrições na década de 1940, iniciando-se em 1931 com a criação da Comissão Nacional de Siderurgia, dentre outros aparelhos de Estado em várias áreas. Dados os limites financeiros e políticos existentes, porém, o escopo e profundidade da intervenção nos ramos básicos não poderiam ampliar-se senão de modo gradual (mas não reativo), avançando desde a tentativa de regular/incentivar empresas privadas até a criação de empresas estatais, não só na siderurgia, como também nos ramos do petróleo e da energia elétrica.

Também não é de surpreender que a conjuntura da Segunda Guerra Mundial aguçasse a consciência industrializante e exigisse maior refinamento nos meios de intervenção. A reconversão dos países centrais para a economia de guerra e os limites ao comércio exterior provocaram desabastecimento de insumos estratégicos, limitaram o crescimento urbano e induziram significativa aceleração da inflação. A necessidade de administrar recursos escassos e priorizar linhas de produção e investimento, por sua vez, aumentou o controle do Estado sobre atividades econômicas, por exemplo, por meio da Coordenação de Mobilização Econômica (CME). Um pouco antes da guerra, o esforço de racionalização dos investimentos públicos contou com a criação do Plano Especial de Obras Públicas e de Aparelhamento da Defesa Nacional (PEOPADN), substituído em 1943 pelo Plano de Obras e Equipamentos (POE) para os cinco anos seguintes. Além disto, a experiência de guerra sedimentou o caminho que poderia ser seguido para resolver estrangulamentos: criar fundos fiscais vinculados a necessidades específicas de infraestrutura e insumos básicos, complementando o esforço local com fundos externos barganhados diplomaticamente, transferidos para instituições públicas. Nos ramos básicos, empresas privadas que resistiam a se arriscar poderiam ser substituídas por empresas estatais, como a Companhia Siderúrgica Nacional, a Companhia Vale do Rio Doce, a Companhia Nacional de Álcalis, a Fábrica Nacional de Motores, a Companhia de Aços Especiais Itabira (Acesita) e a Companhia Hidrelétrica do São Francisco, criadas no período.

Além do esforço para intervenção direta nos ramos básicos, durante a guerra ampliou-se a política de indução seletiva de investimentos privados, através de instrumentos cambiais, fiscais e creditícios. Em primeiro lugar, a guerra propiciou a acumulação de reservas cambiais que poderiam ser usadas para reaparelhar a indústria quando o comércio internacional de bens de capitais fosse normalizado, se houvesse planejamento adequado. Em setembro de 1942, a criação do Serviço de Licenciamento de Despachos de Produtos Importados, na CME, visou priorizar licenças de importação de bens de capital e insumos. ${ }^{3}$ Em janeiro de 1945, a Portaria Interministerial $\mathrm{n}^{\mathrm{O}} 7$ (PI-7) estabeleceu restrições à importação de "produtos sun-

3 Para as memórias de um diplomata que procurava licenças para importar nos EUA, ver Roberto Campos (1994), pp. 72-74. 
tuários e dispensáveis", criando listas de classificação de produtos (dos "supérfluos" aos "essenciais") e propondo a criação de uma agência para orientar o regime de licenciamento de importações. O objetivo era claro: garantir o uso seletivo das divisas acumuladas na guerra quando o comércio internacional se normalizasse. A renegociação da dívida externa ao final de novembro de 1943 também foi saudada como uma iniciativa necessária para liberar divisas para o reaparelhamento industrial no pós-guerra. Vargas diria em 21/12/1943, em discurso proferido na FIESP, que "o maior proveito da operação consiste, porém, na possibilidade de realizarmos o plano de industrialização progressiva do país, no imediato após-guerra" (apud CORSI, 1997, p. 250). Em memorando endereçado a Vargas no início do processo de renegociação da dívida (06/02/1943), o Ministro da Fazenda Souza Costa, às vezes retratado como um representante da "ortodoxia liberal" no governo, sintetizava o objetivo desenvolvimentista da iniciativa:

"A redução da dívida externa se impõe como a mais imperiosa e urgente necessidade nacional. Inúteis serão todos os esforços no sentido de modificar a nossa economia, elevando-a do plano agropecuário em que se tem desenvolvido para o industrial, se não for afastado este peso morto... O Brasil carece de utilizar o seu crédito em novas operações para o reaparelhamento de sua indústria e utilização de todo o potencial econômico que temos para desenvolver" (ARQUIVO GV 43.02.06). ${ }^{4}$

O governo não apenas procurou evitar que as reservas cambiais acumuladas fossem gastas com finalidades "supérfluas", mas buscou forçar empresários a utilizá-las para investimentos novos que substituíssem importações, e que para isto adiassem mesmo decisões de consumo corrente de "produtos suntuários" em moeda local. A política tributária foi usada para isto, pouco depois da renegociação da dívida externa (23/11/1943). Dois decretos simultâneos (DLs no 6224 e 6225, de 24/01/1944) criavam o Imposto sobre Lucros Extraordinários (que taxava excedentes eventualmente alocados para consumo corrente) e permitiam canalizar os impostos devidos para a compra de Certificados de Equipamentos: ao invés de pagar o imposto, os empresários poderiam adquirir certificados no valor correspondente ao dobro do imposto devido, os quais renderiam $3 \%$ ao ano e seriam passíveis de resgate em moeda internacional, exclusivamente para a importação de bens de capital segundo prioridade definidas pelo Estado. Praticamente um ano depois (22/01/1945), a citada Portaria Interministerial $n^{0} 7$ (PI-7) normatizou as prioridades de importações. Com isto, a administração impunha um fundo compulsório que forçava a canaliza-

4 No I Congresso Brasileiro de Economia (25/11/1943): "A regularização definitiva da dívida externa abre assim ao Brasil uma era nova de verdadeira liberdade de ação e...as iniciativas que interessam ao seu desenvolvimento... O fardo dos compromissos financeiros...tornava a independência nacional uma ficção angustiante" (apud CORSI, 1997, pp. 244-6). 
ção da acumulação interna de lucros (estimulada pelo contexto inflacionário) para financiar futuramente a reposição de capital fixo desgastado e novos investimentos do setor privado, assim que as dificuldades de fornecimento fossem normalizadas com a reconversão das economias de guerra.

Isto era uma intervenção sem precedentes sobre as decisões de investimento e consumo, afetando diretamente as rendas dos empresários mais ricos. Cabe lembrar que a taxa de câmbio foi fixada em 1939, tendo o efeito de subsidiar as importações necessárias pelos investimentos por causa da inflação interna (que por sua vez facilitava a acumulação "extraordinária" de lucros dos industriais). Deste modo, criava-se um mecanismo de financiamento dos investimentos adequado ao estágio de diferenciação da estrutura industrial que ainda mantinha os investimentos parcialmente dependentes da capacidade de importar bens de capital. É claro que, como já vinha sendo feito, os fundos privados podiam ser complementados por créditos públicos, oriundos particularmente da Carteira de Crédito Agrícola e Industrial do Banco do Brasil. Assim, embora "o plano de industrialização progressiva do país no imediato pós-guerra" de que falara Vargas não fosse formalizado, um conjunto de mecanismos cambiais, tributários e creditícios foi mobilizado para induzir investimentos nas prioridades desenvolvimentistas do governo, complementando os investimentos estatais nos ramos básicos. ${ }^{5}$

Como se sabe, o golpe que derrubou o Estado Novo e o sucesso da campanha liberal barrou a execução do programa, levou à retração da intervenção e a aberturas comercial e financeira iniciadas no governo provisório e acentuadas no governo Eurico Dutra (ver SARETTA, 2000; BASTOS, 2004). Mas o liberalismo mostrouse inviável: o aumento de importações e remessas de lucro provocaria uma crise cambial que forçou o governo Dutra a um recuo. Restaurou-se, no final de 1947, o licenciamento seletivo de importações tão criticado antes, e evitou-se uma desvalorização cambial de efeitos previsíveis sobre a inflação (considerando, como GUDIN, que nossas exportações eram preço-inelásticas). O efeito da restauração do regime seletivo de importações foi magistralmente identificado por Maria da Conceição Tavares: o bloqueio da importação de bens não essenciais e o barateamento relativo das importações de insumos e máquinas representaram "um estímulo considerável

5 Conferência do Ministro Souza Costa, em 27 de julho de 1945, revela intenção de canalizar lucros acumulados para a modernização industrial através de mecanismos cambiais e tributários heterodoxos: "Os produtos manufaturados acusam alta violenta que ultrapassa de muito o custo de produção. Daí a enorme margem de lucros. São esses lucros acumulados que devem propiciar o reaparelhamento industrial depois da guerra, permitindo baixa acentuada nos preços... É em atenção a esse programa de racionalização da indústria que o governo vem insistindo tanto no congelamento de tais lucros, quando da criação do imposto sobre lucros extraordinários... (daí) o acerto da política econômica do governo, no sentido de proporcionar à indústria a formação de reservas destinadas à renovação das instalações" (ARQUIVO SOUZA COSTA - CPDOC-FGV, séries SC42/44.00.00/lpi e 2pi, e SC45.07.27pi). Para o texto dos decretos, ver E. Carone, 1976, pp. 192-196. 
à implantação interna de indústrias substitutivas desses bens de consumo, sobretudo os duráveis, que ainda não eram produzidos dentro do país e que passaram a contar com uma proteção cambial dupla, tanto do lado da reserva de mercado quanto do lado dos custos de operação. Esta foi basicamente a fase de implantação das indústrias de aparelhos eletrodomésticos e outros artefatos de consumo durável" (TAVARES, 1963, p. 71). Mas uma vez iniciado este processo "espontâneo" de substituição de importações, o governo Dutra, ao contrário das prescrições liberais, procurou atacar alguns estrangulamentos de infraestrutura e financiamento. O Plano Salte, com grandes debilidades financeiras e administrativas, foi anunciado em 1948 para definir investimentos públicos essenciais, enquanto o Banco do Brasil passou a realizar política de crédito mais acomodatícia. Deste modo, restaurava-se, em escala limitada, a combinação entre plano de investimentos, política cambial seletiva, câmbio fixo e política acomodatícia de crédito visualizada no final do Estado Novo.

A reviravolta do governo foi capitalizada, sobretudo por Vargas, cujas críticas apontavam para o caráter "liberal", "anacrônico" e "omisso" da administração que intermediaria seus dois mandatos presidenciais. Não surpreende que Vargas, preparandose para um retorno triunfal, elaborasse nos discursos parlamentares, na campanha presidencial e em memorandos com assessores, um programa que combinava planos setoriais de investimentos e políticas macroeconômicas (nos terrenos cambial, monetário e fiscal) semelhantes ao final do Estado Novo, adaptando-os ao novo contexto e evitando as resistências ideológicas ao anúncio de um plano formal. Surpreende, sim, que, à luz dos escritos e discursos de Vargas, seu novo programa de governo, naquele contexto rico de debates, possa ser caracterizado como meramente "reativo", ou, até no limite, "ortodoxo".

\section{O Projeto Desenvolvimentista: Mecanismos de Financiamento e Gestão Macroeconômica}

Os temas presentes na agenda do final do Estado Novo continuaram relevantes, mas Vargas saiu da posição defensiva quando ,passou para a oposição, disputando não só a forma de resolver como interpretar os problemas em questão. Seu objetivo declarado era aprofundar a intervenção industrializante, garantir o pleno emprego e combater a "carestia" sem sacrificar o crescimento, ou melhor, desacelerar a inflação exatamente por meio do crescimento da oferta. Não se pode entender como se conciliavam no pensamento de Getúlio Vargas a importância de projetos estatais de investimento, orçamentos equilibrados e expansão do crédito na resolução simultânea de problemas de desenvolvimento, inflação e bem-estar social, sem entender 
seu posicionamento crítico frente às crises que, segundo ele, teriam sido produzidas pelas políticas liberais do governo Dutra.

O primeiro sinal de oposição não esperou sequer o fim do autoexílio em São Borja. Quando apoiou publicamente a candidatura de Dutra à presidência, em discurso de 28/11/1945, Vargas fazia questão de frisar que seu apoio não seria incondicional, colocando-se na posição de um fiscal do novo presidente em nome do povo e do Partido Trabalhista Brasileiro (PTB):

"A abstenção é um erro... O momento não é de nomes, mas de programas e de princípios... aconselhei aos trabalhadores que cerrassem fileiras em torno do programa do Partido Trabalhista Brasileiro, representante e defensor de seus interesses. O general Eurico Gaspar Dutra, candidato ao PSD, em repetidos discursos e, ainda agora, em suas últimas declarações, colocouse dentro das idéias do programa trabalhista e assegurou a esse partido garantias de apoio...Ele merece, portanto, os nossos sufrágios. Sempre procurei atender aos interesses dos pobres e dos humildes, amparar os direitos dos trabalhadores $e$ do povo brasileiro em geral, desse povo sempre bom, bravo $e$ generoso. Estarei ao vosso lado para a luta e acompanhar-vosei até a vitória. Após esta, estarei ao lado do povo, contra o presidente, se não forem cumpridas as promessas do candidato" (A POLÍTICA TRABALHISTA DO BRASIL, PP. 15-6).

Com esta declaração, Vargas buscava se afastar da "classe política" e justificar que a influência que o PTB teria na indicação do novo Ministro do Trabalho não resultava de mera barganha fisiológica, mas vinculava-se a um programa a que o candidato havia se comprometido: garantir os direitos trabalhistas "consolidados" por Vargas no Estado Novo; respeitar o "direito ao trabalho" na gestão da política econômica, como o ex-presidente não iria demorar a cobrar. ${ }^{6}$ A atitude de fiscalização, desde uma postura programática diferente, marcaria gradualmente os posicionamentos de Vargas. Pouco depois de manifestar oposição na sede do PTB gaúcho em setembro de 1946 (elogiando o planejamento econômico contra o desmonte liberal das "autarquias e institutos que amparavam produtores e consumidores"), e de criticar os partidos que defendem a "velha democracia liberal que afirma a liberdade política e nega a igualdade social" em comício de novembro, Vargas realizou um longo balanço

6 Além de direitos como salário mínimo, férias remuneradas, representação sindical, $13^{\circ}$ salário, limitação da jornada e aposentadoria, o programa do PTB sublinhava aquilo que Vargas chamava de "direito ao trabalho", ou seja, o repúdio ao desemprego: "Oportunidade a todo indivíduo para trabalhar em emprego útil e regular, mediante salário razoável que lhe permita, em um máximo de oito horas de jornada, obter os meios necessários ao sustento próprio e de sua família de maneira condigna" (apud CARONE, 1980, pp. 433-436). 
de seus quinze anos de governo no Senado (13/12/1946), enumerando realizações sociais (direitos trabalhistas) e econômicas (financiamento de investimentos), e defendendo-se das críticas do final do Estado Novo. Finalmente, saindo da defensiva em comício da campanha de Bias Fortes ao governo de Minas Gerais (06/01/1947), sublinharia frontalmente as diferenças entre seu governo e o atual, enfatizando a forma de condução da política de crédito:

"Transportei para estas montanhas, como glória, a acusação de que dei ordem ao Banco do Brasil para que fizesse o financiamento da pecuária mineira. Sim, dei essa ordem e novamente a daria, se tivesse podido fazê-lo. Jamais deixaria os trabalhadores rurais de Minas, os fazendeiros, os que criaram a grandeza de nosso interior nas vascas da agonia de uma falência ou moratória" (idem, p. 122).

O objetivo era defender um legado (ter iniciado a "batalha da produção" e defendido o "direito ao trabalho") e afirmar que seu desmonte deixava de atender às aspirações nacionais e populares, sob a alegação duvidosa de combater a inflação. Seu posicionamento tornou-se claro, e vigorosamente oposicionista, em meados de 1947. O último dos cinco discursos no Senado (03/07/1947) concluiu o desagravo em pouco mais de um semestre, em que acertava contas com o passado e passava à oposição aberta ao intitular-se defensor dos interesses do povo contra a "ditadura econômico-financeira que está funcionando como um garrote contra todas as forças da produção...ditadura mais rígida, mais severa, mais inabalável e irredutível do que a que se derrubou" (idem, pp. 267-8).

Antes de abordar o modo como Vargas tratou no período das relações existentes entre política monetária e creditícia, inflação, déficit público e desemprego, cabe frisar que a ideologia trabalhista de Getúlio Vargas sempre procurou enfatizar: 1) a existência de interesses convergentes entre trabalhadores e empresários, em um esforço de neutralização dos comunistas; 2) que esta convergência far-se-ia garantindo direitos trabalhistas regulados por lei, mas tendo como condição a expansão dos frutos do progresso econômico a serem divididos entre as classes. De fato, repetidas vezes durante seus quinze anos de governo, Vargas afirmara que o desenvolvimento econômico era necessário para garantir a coesão social interna, permitindo elevação dos salários reais ("valorização do trabalho") graças à oferta de empregos de produtividade maior e à elevação do piso salarial. Coerentemente, agora fora do governo, Vargas buscava se apresentar não apenas como patrono das leis sociais no Brasil, mas também como campeão da "batalha da produção", condição de conciliação de interesses entre as classes e anteparo contra o comunismo. Quanto a isto, ele seria muito claro no referido discurso na campanha de Bias Fortes em Minas: "Um dos 
nossos mais notáveis espíritos liberais, o eminente Antônio Carlos, disse: 'Façamos a revolução antes que o povo a faça'. E hoje vos exorto a fazer a evolução antes que o povo faça a revolução" (idem, p. 120). Ou seja: reformismo (político-social) e progresso (econômico) estavam intimamente articulados na ideologia trabalhista de Vargas, em geral, assim como estariam particularmente presentes em suas críticas à política econômica do governo Dutra. O último dos cinco discursos no Senado não deixaria dúvidas:

"Sr. Presidente, a industrialização é o anseio de todos os povos, porque a indústria representa a fase mais elevada da civilização... Como se combater o pauperismo sem a valorização do trabalho? Como se valorizar esse trabalho sem (garantir) eficiência? Como se alcançar eficiência sem a multiplicação do valor do homem pela energia da máquina?.. Como justificar, em face desse conceito, a indiferença com que se fala em fechar fábricas e despedir milhares de operários? Se o plano monetário tem a conseqüência do desemprego de dezenas de milhares de operários, pode estar certo, financeiramente, mas socialmente está errado. E errado está sob o ponto de vista da solidariedade humana" (idem, pp. 252-3;297-8).

Desta maneira, Vargas explicitava como nunca a motivação ideológica de seu repúdio à política anti-inflacionária seguida pelo governo Dutra: o "direito ao trabalho" deveria sobrepor-se à ortodoxia monetária de velho tipo, pois o "plano monetário" não poderia ter como consequência o desemprego em massa; financiar a industrialização, por sua vez, seria meio de superação do "pauperismo" e condição para a coesão social. Mais que isto, para Vargas a política de contração creditícia de Dutra não era errada somente à luz das consequências sociais que trazia; ela não seria correta sequer como meio para combater a inflação. Não será ocioso sublinhar esta questão, porque a heterodoxia revelada por Vargas é notável no modo como concebia as relações entre oferta de moeda, déficit público e inflação, e é crucial para que se entenda seu projeto de governo posterior. De fato, seu ataque à política econômica centrou-se na questão do crédito como meio de combate à inflação. Para ele, o país não se encontrava em uma situação "saturada" em que a produção não pudesse aumentar sob o estímulo da política creditícia. Isto ficaria muito claro não apenas nos documentos preparatórios de seus discursos, mas nos próprios discursos, como a seguir, em 30 de maio de 1947:

"Parece lógico que a solução para o problema (de assegurar que meios de pagamentos estejam em relação conveniente com o volume total de bens e serviços) não é restringir créditos e, sim, 
aumentar a nossa produção e riqueza, aumentando, portanto, os bens, as mercadorias e os serviços. Creio até que, se bem não me engano, esta é a opinião de vários ilustres membros desta Casa... Mas não é esta a opinião do ilustre Presidente do Banco do Brasil, orientador geral da economia e das finanças nacionais. 'A produção', declara sua senhoria em seu Relatório - 'não se pode desenvolver de modo ilimitado'. E continua dizendo mais ou menos o seguinte: que, existindo excesso de meios de pagamento e não existindo possibilidade de aumento de produção, é indispensável reduzir os meios de pagamento. Doutrinariamente, esse ponto de vista estaria certo, se não houvesse mais possibilidade de aumento de produção, isto é, se o Brasil tivesse alcançado a saturação econômica. O grande mal de ler muitos livros estrangeiros, sem traduzir os problemas, limitando-se à tradução das palavras, reside precisamente nisso. Irving Fisher escreveu dentro do problema norte-americano e nós nos encontramos num país onde podemos verificar um sub-consumo e uma sub-produção. Muito longe de alcançarmos o ilimitado, precisamos produzir, e produzir muito, para a grandeza de nosso País e bem-estar de nosso povo... Se há falta, bens, mercadorias e serviços ainda se podem desenvolver, estando, assim, muito longe do limite de saturação" (idem, pp. 230-1). ${ }^{7}$

Vivendo-se uma situação em que a produção podia aumentar se o crédito estivesse disponível, uma política de expansão do crédito não seria absorvida por elevações de preço. Por outro lado, uma política de contração do crédito afetaria diretamente os níveis de produção e emprego. Mas sem necessariamente reduzir nem as emissões nem os preços: a contração do crédito seria acompanhada pela ampliação do déficit público (e das emissões fiduciárias), de um lado, pela redução da oferta de bens e pela elevação dos custos de produção, de outro. Criticando Dutra, Vargas também defendia a orientação financeira seguida antes por seu próprio governo, no seu principal e mais polêmico discurso no Senado, em 3 de julho de 1947:

"Desde 1930 até 1944, os meios de pagamento passaram do índice 100 para o indice $720 \ldots$.. emissão de papel-moeda não tem uma relação tão estreita com os preços, conforme se afirma... Os que falam em baixa de produção em relação ao aumento de meios de pagamento, é preciso que reflitam sobre o indice de aumento de volume não só dos gêneros alimentícios como das matérias pri-

7 Em um estudo de 1946, que orientaria seus discursos no Senado (GV 46.00.00/13), lê-se: "A 'concepção financeira' do Brasil coloca todos os males como consequência da emissão de papel moeda. Mas na realidade essa emissão de papel moeda só é prejudicial quando a produção não a acompanha". A respeito, ver carta a A.J. Rener de 19/10/1949 (GV 49.10.18). 
mas, que, de 100 em 1929, passou para 354 em 1944, e o índice de produção industrial básica, que, de 100 em 1929, passou para 1.217 em 1944. Relativamente à produção industrial brasileira, não existe uma estatística completa...Temos, porém, possibilidades de chegar a uma estimativa bem superior ao indice de 700, considerando-se produção industrial a atividade de construção civil. Não há um desequilíbrio tão violento entre os meios de pagamento e os bens de consumo. E este ponto é, precisamente, o 'calcanhar de Aquiles' da orientação monetária do governo. E é precisamente devido a esse erro que a produção nacional se reduzirá na proporção da redução dos meios de pagamento, porque inegavelmente tivemos (no governo anterior) um forte aumento não só no meio circulante como na moeda escritural. Mas isto representava apenas a média geral das necessidades de desenvolvimento de um país. Numa situação de economia já saturada, esse aumento de meios de pagamento pode determinar grandes crises. Numa nação como o Brasil, de economia em evolução, o aumento dos meios de pagamento, acompanhado pelo aumento de bens de consumo - que, como se está verificando, se efetuou - e ainda por uma elevação proporcional da tributação, que retira os excessos da circulação pelo meio fiscal, não representa o menor perigo. Perigo, sim, é a redução dos meios de pagamento. E tanto mais grave quando vai alcançar toda a estrutura do Estado e não somente a vida econômica do país" (idem, pp. 259-261).

A contração creditícia alcançaria "toda a estrutura do Estado" porque, segundo Vargas, implicaria elevação do déficit público por conta da contração das receitas fiscais (dependentes do nível de atividade econômica) e, assim, não implicaria redução das emissões primárias. Em outras palavras, uma política creditícia contracionista acabaria sendo acompanhada por uma política monetária de direção inversa. Tudo se passaria como se a redução da moeda escritural de crédito acabasse compensada (pelo menos em parte) pela expansão não programada da moeda fiduciária por causa do déficit público, em prejuízo de níveis de renda, emprego e arrecadação tributária:

\footnotetext{
"Pensávamos todos, no Brasil, que o louvável esforço em se controlar o ritmo emissionista não significaria a drenagem de todos os recursos destinados à produção para o Banco do Brasil poder atender a despesas do governo...Quem está defendendo o governo? Eu, que chamo a atenção para a gravidade da redução dos meios de pagamento, afetando as possibilidades de recursos financeiros da administração pública, ou quem efetua essa redução de meios
} 
de pagamento, destrói todas as possibilidades dos orçamentos Federal, Estaduais e Municipais, e coloca o governo na impossibilidade de dispor de meios" (idem, pp. 249, 261).

O problema de um mix de política creditícia contracionista e política monetária expansionista era que a expansão da produção dependia do crédito. Vargas diferenciava o impacto das emissões fiduciárias derivadas do déficit fiscal, do impacto da expansão da moeda por meio do crédito bancário: enquanto o crédito bancário podia vincular-se a uma expansão da oferta produtiva, um déficit orçamentário poderia não o fazer, se o déficit público resultasse de contração de receitas e não de aumento de despesas, e se a política de crédito estrangulasse a expansão da produção. Vargas concordava com a necessidade de uma política orçamentária equilibrada (“... ainda não aprendi como fazer efetiva e eficientemente deflação sem se alcançar o equilíbrio orçamentário”), mas alegava que o efeito da política creditícia contracionista era, de um lado, o de reduzir a oferta de bens, e, de outro, ampliar o déficit orçamentário e, por esta via, as emissões fiduciárias sem contrapartida produtiva: "Iremos reduzir os meios de pagamento e a produção, sendo que esta em proporção muito maior do que a dos meios de pagamento, porque o governo, na proporção que for desenvolvendo seu programa, será obrigado a emitir cada vez mais..." (p. 264). Além de provocar déficit público e recessão (pela queda da velocidade de circulação da moeda), a elevação das taxas de juros criaria uma pressão inflacionária ao elevar custos de produção
"Nega-se ao trabalhador uma parcela de dinheiro para reajus- tamento de seus salários, alegando-se que isso afetará o custo de produção. Mas aumenta-se a parcela de juros do dinheiro, que hoje só circula em câmbio negro. O custo de produção não baixa. Antes pelo contrário: com a redução de meios para desenvolver-se, esse custo aumenta cada vez mais" (idem, pp. 283-4). ${ }^{8}$

O ponto importante a frisar é que, para Vargas, o resultado orçamentário e, portanto, a emissão de moeda fiduciária para atender às necessidades do Tesouro, dependeria diretamente de uma política de crédito que não estrangulasse a expansão do ritmo de atividade econômica e o desempenho da arrecadação tributária. Assim, a expansão do crédito seria favorável ao combate à inflação seja ao conter o déficit público (através de seus efeitos sobre as receitas tributárias), seja pela expansão da oferta de bens (através do financiamento da produção corrente e do investimento produtivo), ou, ainda, pela redução dos custos de produção (através do controle dos custos de crédito). Isto é: um mix de orçamentos equilibrados e expansão creditícia não era, segundo Vargas, incoerente, mas sim obrigatório no combate à 8 Vargas abordou a questão também em seu discurso anterior, em 30/05/1947. 
inflação. Para Vargas, não parecia apenas possível reduzir a inflação e crescer ao mesmo tempo - isto era imperativo. Ademais, não limitava suas críticas à questão da eficácia da política anti-inflacionária do governo Dutra: atacava diretamente a hierarquia de interesses socioeconômicos propostos por ela. Segundo ele, além de ser contraproducente no combate à inflação, esta política estaria promovendo uma grande redistribuição de poder e riqueza, prejudicando trabalhadores, empresários e instâncias de governo para favorecer a alta finança; diante disto, Vargas apresentava-se como porta-voz dos grupos atingidos e forte crítico do grupo beneficiado, sugerindo reverter esta hierarquização perversa:

"Nada mais estou fazendo do que isto: provar que estão errados $e$ evidenciando até que um dos erros maiores é o do cerceamento do crédito...Sr. Presidente, a criação do monopólio do dinheiro, que se está efetuando no Brasil, representa uma das mais impressionantes ofensivas do poder financeiro contra a produção e contra os valores do trabalho e de iniciativa... A alta finança, que tinha perdido o controle sobre a economia brasileira devido à ação do governo (anterior), que facilitava aos produtores os recursos necessários todas as vezes que os grupos financeiros os negavam, domina o Presidente da República e está governando o país. As forças de produção estão sendo subjugadas e aniquiladas." (pp. 283-4).

Era então para combater este aniquilamento que Vargas saíra do exílio, respondendo aos clamores de seus eleitores, que apenas pediam "como cidadãos brasileiros, que não se lancem suas famílias ao desespero do desemprego. Pedem que não se transforme em miséria o que era esperança de bem-estar...Estão pedindo a esta Casa que reconheça o direito de trabalhar" (p. 288).

É inegável que o posicionamento público de Vargas o recolocava no centro do cenário político, visando interpelar os grupos sociais prejudicados e questionar a competência técnica e as opções políticas dos responsáveis pela política econômica - exatamente como a campanha liberal fizera antes. Vargas acertava contas com o passado: no foco das críticas, a política de crédito; por trás dela, uma ordenação hierárquica que subordinava as "forças da produção" e o "direito ao trabalho" à "ditadura econômico-financeira" dos ambiciosos "intermediários do dinheiro”, sob a alegação falaciosa de buscar um interesse geral, o combate à inflação. Combate que, segundo Vargas, estaria fadado ao fracasso caso não se apoiasse na expansão da produção e no equilíbrio orçamentário, ambos possíveis apenas com uma política creditícia que, ao mesmo tempo, não boicotasse a coesão social com a difusão da miséria, do desemprego e da desesperança. E, sobretudo, que não alimentasse o espectro do comunismo e da agitação social (segundo argumentaria em 11/11/1946, 
antes do banimento do PCB): "A evolução política do Brasil se deve processar em ordem, com disciplina e respeito às autoridades. Não precisam nem precisarão os trabalhadores do Brasil recorrer a greves, porque a bancada trabalhista, na Câmara e no Senado, defenderá intransigivelmente as fórmulas mais práticas para a solução dos seus problemas" (idem, p. 45) — como, ao que parece, Vargas pretendia fazer ao criticar a política econômica do governo Dutra.

Além de reforçarem a identificação de Vargas com os "pobres e humildes", seus argumentos sensibilizavam empresários prejudicados pela política de contração creditícia desde a gestão Pires do Rio, e exacerbada no início da gestão de Guilherme da Silveira no Banco do Brasil (1946-1949), antes que este assumisse o Ministério da Fazenda e rompesse com as políticas do chamado "grupo sumoqueano" (LAGO, 1982). No período, documentos e declarações de organizações e congressos empresariais propunham, como Vargas, que o combate à inflação fosse contraproducente caso acompanhado da retração do crédito, pois estrangularia a expansão da oferta agregada. Agora na oposição, Vargas culpava a "ditadura econômico-financeira" que teria se instalado no país para "sugar" os esforços da produção, chegando a afirmar que o presidente do Brasil não era Dutra, mas sim Guilherme da Silveira, assim como Joaquim Murtinho fôra no lugar de Campos Salles. ${ }^{9}$

É evidente a linha de continuidade entre o posicionamento de Vargas na oposição ao governo Dutra e a plataforma eleitoral que defendeu na campanha presidencial de 1950. Era o próprio Vargas que se esforçaria para frisar esta continuidade em seu primeiro discurso da campanha de 1950:

"Não desconheço a gravidade da situação econômica e financeira em que se debate o país. Fui o primeiro a denunciá-la da tribuna do Senado e - aí de nós - meus vaticínios saíram infelizmente certos...Durante minha administração mantive, quando necessário, o regime de controle cambial estritamente para regular as importações, regime abolido pelo governo Linhares e só restabelecido pelo atual quando a invasão de mercadorias, muitas delas supérfluas, e a fuga de nossas disponibilidades cambiais deixaram o país endividado com os exportadores estrangeiros...Atribuindome a pecha de inflacionista, entregou-se, no começo, o governo a uma restrição de crédito súbita e perigosa, que arrastou casas de comércio, fábricas e até bancos à moratória ou à falência, e paralisou, já não direi o surto de novas indústrias, mas a estabilidade das existentes, contribuindo assim mais para atrelar-nos à dependência estrangeira em muitos ramos de produção em que

9 A Política Trabalhista do Brasil, pp. 268-270. Sobre a posição dos empresários, ver Bielschowsky, 1985, pp. 363-5. 
já triunfara o similar brasileiro... Não é esta hoje, uma plataforma de governo no desacreditado estilo dos tempos passados... Homem de governo, não descurarei, igualmente, os meus deveres para com as forças — hoje combalidas — da produção nacional em qualquer de seus ramos, estabelecendo uma política orgânica de assistência aos interesses do comércio, da indústria e da agricultura... Urge retomar o programa de amparo à industrialização progressiva do país, dando prioridade às indústrias de base..." (A CAMPANHA PRESIDENCIAL, pp.23-9). ${ }^{10}$

A campanha repetiu um mesmo ponto: “...retomar o programa de amparo à industrialização progressiva do país, dando prioridade às indústrias de base”, mas sem se limitar a elas, recuperando programas de fomento da produção (agrícola e industrial) que haviam sido negligenciados, corrigindo erros da política de crédito e câmbio e aprimorando o planejamento e financiamento da expansão industrial para novos setores. Ainda que em cada região Vargas apontasse gargalos específicos (suprimento de energia, meios de transporte, armazenamento etc.), a questão do financiamento era central. Para regiões agrícolas, a superação de problemas de infraestrutura deveria ser complementada de política de preços mínimos e, sobretudo, financiamento barato aos produtores; para a indústria, vários gargalos seriam enfrentados, particularmente a carência de créditos a maior prazo e menor custo. Era Vargas quem apontava a centralidade da questão financeira:

"Julgo que o ponto alto da maioria dos problemas que nos defrontam está no crédito acessível, reprodutivo e suficiente. Não será demais insistir em que sem crédito abundante, sem juros módicos,

10 Vargas voltaria ao tema logo depois, em seu primeiro discurso em São Paulo: "Sobrevinda a (Segunda) Guerra, prestou-se, imediatamente, por intermédio da Carteira de Crédito Agrícola e Industrial do Banco do Brasil, larga assistência financeira ao produtor...É conhecida de todos a política posteriormente adotada. O governo abandonou a lavoura e a indústria algodoeira à sua própria sorte...As desastrosas conseqüências dessas e de outras medidas, quando apenas se esboçavam, fizeram com que erguesse a minha voz, no Senado da República, clamando por providências que evitassem a crise, como desfecho natural e desenlace lógico da orientação governamental contrária ao desenvolvimento da produção...A minha advertência não foi, porém, ouvida. Mas as minhas previsões se confirmaram no doloroso cortejo das desalentadoras realidades atuais" (A Campanha Presidencial, pp. 59-61). E em seu primeiro discurso no Rio de Janeiro: "Previ o que ia acontecer. Avisei...E o que devia acontecer, aconteceu. As nossas reservas no exterior, 700 milhões de dólares, volatilizaram-se na importação de inutilidades luxuosas e em transações ruinosas para os interesses do Brasil. A inflação, a verdadeira inflação, veio pelas emissões a jato contínuo para cobrir déficits orçamentários...A falta de crédito à produção provocou a estagnação desta" (idem, pp. 98-9). Falando sobre a crise da carnaúba no Piauí: "Embora se pretenda atribuir este fato à cessação da guerra, a verdade é que não foi essa circunstância a responsável pelo ocorrido, mas, sim, a grave retração de crédito verificada em todos os setores da atividade mercantil, como decorrência da orientação governamental, e que atingiu, em particular, a indústria da carnaúba. No Senado, em 1947, lancei uma advertência ao governo, assinalando os danos acarretados à economia do Nordeste pelas medidas postas em prática. Clamei contra a falta de financiamento..." (idem, p. 160). 
sem permanente e estimuladora assistência financeira, será impossível levar a economia nacional à plenitude de suas realizações. Na solução do problema da madeira, do mate, do café e de tantos outros, a minha concepção se enquadra principalmente em um enunciado singelo: crédito, porque sem crédito morreremos de inanição..." (idem, p. 508). ${ }^{11}$

O tema da coesão social e da convergência de interesses entre proprietários e trabalhadores também continuou crucial em sua concepção a respeito da condução da política de crédito; ela deveria assegurar que os proprietários aplicassem sua riqueza "em funções reprodutivas" em vez de gozarem da "função de usurários", pois assim estaria preservado também o "direito ao trabalho", central à ideologia trabalhista e à sua proposta em defesa do compromisso de classes. Para isto, seria fundamental inverter finalidades e meios de ação no trato do dinheiro:

"A política econômica e financeira do governo atual tem sido a política da valorização do dinheiro e da desvalorização do trabalho... a valorização do dinheiro na mão dos que têm dinheiro e que não aplicam este dinheiro com finalidades sociais. Não sendo capazes de criar uma indústria e empregar esse capital em qualquer atividade produtiva, eles se reservam, no momento em que o governo nega crédito às forças produtivas para, na sua função de usurários, emprestarem o dinheiro a 12, 14, 18 e 20 por

11 Para não deixar dúvidas, afirmar-se-ia que "será esse - o financiamento à produção - o ponto a que consagrarei a maior atenção se voltar ao governo, levado pelo voto popular" (idem, p. 246). Cabe frisar que Vargas associava a importância do crédito à própria institucionalidade de economias modernas caracterizadas pela complexidade da divisão social do trabalho; nelas, ao contrário da "economia de uma sociedade embrionária (que) repousa em pequenas iniciativas individuais, tomadas isoladamente", as relações de crédito deixariam de assumir caráter meramente "subjetivo", individual e esporádico, de modo que "o crédito torna-se, então institucional". Neste contexto institucional, a oferta de crédito deveria preservar uma alta relação com o valor agregado na agricultura, na indústria e no comércio: "Não se verificam mais as relações simples e arbitrárias entre o banqueiro - de um lado - e o lavrador, o industrial, o comerciante e o trabalhador - do outro. Estamos diante de relações complexas, entre o sistema bancário e a lavoura, a indústria, o comércio e os trabalhadores em geral". Agora, a contração da confiança no crédito teria necessariamente consequências gerais (e não individuais) indesejáveis, pois o crédito tornara-se elemento permanente e indispensável para a ampliação "da produtividade e de desenvolvimento da riqueza, fontes de orientação e organização da política de expansão do crédito". Caberia, logo, rejeitar concepções atrasadas de gestão da política creditícia e colocar o crédito a serviço da expansão da produção: "A mentalidade bancária do nosso tempo, que se deve caracterizar por um sentido eminentemente social, não pode, portanto, ficar tolhida por métodos arcaicos, oriundas de concepções contemporâneas de estágios econômicos há muito superados" (pp. 279-280). O tema, na verdade, não era novo, tendo sido antecipado mesmo antes de 1930: cf. P.C. Fonseca (1987), pp. 99 e segs; nem seria esquecido, sendo repetido na passagem da Mensagem Presidencial de 1951 em que se afirmava que o volume de crédito destinado aos agregados econômicos "indústria" e "agricultura", graças à carência de recursos da CREAI-BB e à falta de habilidade dos bancos privados, era insignificante em vista das "necessidades" institucionais (G. VARGAS, MENSAGEM..., 1951, PP. 83-4). 
cento. É isto o que eu denomino de valorização do dinheiro. Desde que o dinheiro seja concentrado nas mãos de poucos, desde que o governo não forneça crédito para o desenvolvimento da iniciativa privada, o trabalho vai rareando...Portanto a política que se está seguindo, da valorização do dinheiro, é a da desvalorização do trabalho, é precisamente a política da perseguição do trabalhador e da produção; ao passo que a política que nós devemos fazer é a do barateamento do dinheiro para que todos tenham trabalho...E para que todos tenham oportunidade de trabalhar é preciso que não lhes falte o necessário crédito, sempre que tenham uma boa idéia a executar. É exatamente o inverso do que se está fazendo atualmente, o que é preciso fazer para o futuro" (pp. 555-6).

Rejeitando o enriquecimento artificial das elites intermediárias do dinheiro, de um lado, e as "infecções ideológicas exóticas e dissolventes", de outro, Vargas propunha um "caminho do meio", fundamentado na inversão produtiva do capital e na garantia do "direito ao trabalho": "Nem a ditadura do proletariado, nem a ditadura das elites. O que a sociedade moderna aspira é o trabalhismo — ou seja a harmonia entre todas as classes, a democracia com base no trabalho e no bem-estar do povo" (p. 419). Nos termos deste compromisso de classes, o fomento da produção através do crédito seria um forte anteparo contra a elevação do custo de vida e contra o comunismo, assegurando o bem-estar coletivo e a paz social por meio do crescimento da renda e do emprego. ${ }^{12}$

A política cambial era outro foco de críticas, e não poderia ser diferente: vimos como no Estado Novo foi montado esquema de financiamento de investimentos, através de regime de licenciamento prévio e seletivo de importações (a PI-nº articulado à constituição de fundos compulsórios (Decretos-Lei 6224 e 6225) e à oferta de crédito pela CREAI-BB. Como Vargas fazia questão de lembrar em seu primeiro discurso na campanha presidencial, o regime de licenciamento de importações foi abolido no governo Linhares e retomado, com Dutra, apenas depois da crise cambial. Ao longo da campanha, Vargas não perdeu oportunidades para sublinhar a imprevidência de seus sucessores e reafirmar que a utilização das divisas deveria ser feita priorizando a importação de "bens reprodutivos", recusando pedidos de importações de bens com similar nacional:

12 "Isso será, apenas, a contribuição de qualquer governo bem intencionado, que se coloque ao lado do povo, e compreenda que o amparo à produção e ao trabalho, além de beneficiar o Brasil, do ponto de vista econômico, diminuirá a nossa inquietação social, causada pelo preço exorbitante da vida que cada vez mais se eleva e permitirá levar às classes menos favorecidas a porção de alegria e conforto a que têm direito" (idem, p. 410). A união de crescimento econômico e coesão social seria reforçada pela defesa dos direitos trabalhistas adquiridos: idem, pp. 49, 142, 148, 419, 490, $533,587,595$ e 629. 
"Tendes experimentado surpreendentes e profundos golpes, oriundos da nossa política comercial externa, a qual permite, sem maior cuidado, a importação de similares estrangeiros. Cumpre-nos regular esse comércio internacional, de forma que ele não venha a prejudicar nossas próprias indústrias. Se merecer a maioria dos sufrágios do país, retificarei a orientação que vem sendo seguida a esse respeito pelos responsáveis pela administração pública, só abrindo o mercado interno à produção estrangeira, quando assegurado o inteiro consumo da nacional" (p. 574).

Assim, Vargas reafirmava o compromisso com a "batalha da produção" e o estendia para o campo da política cambial e comercial. ${ }^{13}$ Rejeitando políticas ortodoxas de restrição generalizada da oferta de moeda (o "desacreditado estilo dos tempos passados", os "métodos arcaicos"), a Vargas parecia impossível reduzir a inflação sem crescer ao mesmo tempo - de modo que aumentar a produção e reduzir o custo de vida não seriam metas a realizar em diferentes "fases" de um mesmo governo. $\mathrm{O}$ combate à inflação deveria ser realizado em duas frentes, simultâneas e complementares: ampliar a produção com o apoio decidido das políticas cambial e de crédito, e assegurar o equilíbrio orçamentário. Segundo ele, exatamente o inverso do mix de política creditícia e fiscal-monetária do governo Dutra criticado como desastroso (idem, pp. 281 e 363).

Na única vez em que tratou longamente da questão orçamentária (e, não, como afirmaria VIANNA, 1987, p. 35, "no único discurso em que se detém sobre os problemas econômicos do país"), diria que "todo e qualquer programa de desenvolvimento econômico será fadado ao fracasso irremediável, como o foram os ultimamente ensaiados, desde que não contem com o amparo de uma política que oriente, equilibradamente, as finanças públicas" (idem, p. 65). Mas foram frequentes as referências à necessidade de conjugar, ao equilíbrio orçamentário, uma política de expansão do crédito. ${ }^{14}$

13 Vargas voltaria à questão outras vezes durante a campanha presidencial, esclarecendo suas prioridades no uso das divisas: "Quando deixei o governo, logo depois do conflito mundial, o Brasil era, pela primeira vez na sua história, credor internacional, através de divisas que tinham valor ouro...Que fizeram desse dinheiro? Por quê não compraram material para o reaparelhamento dos nossos transportes? Por quê não adquiriram máquinas, sondas e perfuratrizes para incrementar a pesquisa e desenvolver a produção de petróleo? Por quê fundiram nossas reservas em quinquilharias, automóveis, em objetos de luxo, em coisas que não aproveitam à comunidade, que não criam riqueza?" (p. 257); ou na seguinte passagem: "Durante a segunda guerra mundial, através de sacrifícios sem conta, trabalhamos todos para acumular riqueza pública. Em nossa já longa vida independente, pela primeira vez, chegamos ao fim da guerra na situação de credores das grandes nações industriais do mundo... Sabeis o destino melancólico dessas vultuosas reservas? Transformaram-se em bugigangas, em ouropéis e enfeites, como no tempo dos índios. Em lugar de bens reprodutivos, compramos contas e miçangas" (pp. 474-5).

14 Diria de improviso em Rio Grande (RS): "Nós precisamos defender o produtor estabelecendo um preço mínimo para a venda de seus produtos e permitindo-lhe o financiamento oportuno... Não se 
Se é verdade que Vargas propunha, de um lado, assegurar crédito "fácil e barato" junto ao Banco do Brasil e, de outro, destinar divisas para atividades complementares (não competitivas) às indústrias aqui instaladas, o retorno ao que chamara de "um nacionalismo econômico moderado, mas eficiente" não deveria envolver uma recusa à "cooperação internacional" para o financiamento de investimentos industriais. Embora Vargas frisasse a necessidade de regular a entrada de capitais, não prescindia de financiamento externo, desde que se preservasse o controle nacional dos recursos naturais imprescindíveis à defesa nacional, como o petróleo (a "ser explorado por brasileiros com organizações predominantemente brasileiras": idem, p.258); e caso se assegurasse a vinculação dos investimentos estrangeiros às necessidades de desenvolvimento do país:

"Não sou, como tendenciosamente afirmam forças reacionárias, inimigo da cooperação do capital estrangeiro. Ao contrário, convoquei-o muitas vezes a cooperar com o Brasil durante os anos de minha administração. Sou adversário, sim, da exploração do capitalismo usurário e oportunista, visando exclusivamente o lucro individual e fugindo à função mais nobre de criar melhores condições de vida para todos. Por isso, sempre preferi e continuo a preferir, como método de ação, o sistema das sociedades de economia mista..." (p. 303).

Neste sentido, sua postura era coerente àquela que esposava em relação ao capital interno: era necessário, sobretudo através de joint ventures, garantir a inversão produtiva (e não "usurária") do capital para articulá-lo às diretrizes públicas. Estas joint ventures deveriam desenvolver ramos pesados de bens de produção (cujos requisitos financeiros estavam além do setor privado nacional, ainda quando apoiado pela CREAI-BB). O problema mais emergencial visualizado por Vargas na campanha, porém, era a possibilidade de deflagração de um novo conflito militar em escala mundial:

"O futuro do Brasil está hoje em jogo, mais do que em qualquer oportunidade semelhante. Dos países estrangeiros hoje chegam os ruídos ameaçadores de conflito, próximo ou distante. Que será de

pode baratear a vida sem aumentar a produção e não se pode aumentar a produção fazendo uma guerra de morte contra os produtores" (idem, p. 598; ver p. 636). Voltaria à questão no penúltimo discurso da campanha, dando-lhe um sentido geral: "A campanha que estamos desenvolvendo e a pregação que vimos fazendo através de vários Estados do Brasil, são no sentido da recuperação econômica da Pátria e da valorização do trabalho. A recuperação econômica tem em suas finalidades principais, conseguir o barateamento da vida. Mas para conseguir o barateamento da vida é necessário aumentar a produção, e não se aumenta a produção fazendo, como faz o atual governo, uma guerra de morte contra a indústria, o comércio e a lavoura...o que se torna necessário a fim de aumentar a produção é amparar o produtor com crédito barato e fácil, com crédito a juros baixos e a prazo longo" (p. 652). 
nosso povo, em face de uma possível terceira guerra mundial? A última teria sido para nós verdadeiramente calamitosa, não fossem as precauções tomadas pelo meu governo. Agora, desfalcados de matérias-primas industriais, se irromper uma conflagração mundial, soçobraremos como embarcação sem bússola. Tudo ou quase tudo ficará paralisado e regrediremos meio século. Esse o panorama do futuro se errarmos na escolha...não é possivel que nos façamos co-responsáveis pelos dias sombrios que o futuro nos reserva" (p. 546).

Vargas não incorria em veleidade retórica, ao afirmar ser urgente reagir à deflagração de uma guerra mundial que desfalcasse o país de insumos essenciais: se antecipando aos acontecimentos já recebera em setembro um relatório elaborado por Walder Sarmanho, ministro de segunda classe da Embaixada Brasileira em Washington (ex-chefe de gabinete de Vargas, por mais de dez anos), a ser promovido à primeira classe por Vargas um ano depois. Neste relatório, intitulado "Sugestões para a Defesa Econômica do Brasil em Situação de Emergência” (GV 50.09.03), árias iniciativas emergenciais para assegurar o abastecimento do país eram analisadas e sugeridas. ${ }^{15}$

Na Mensagem Presidencial de 1951, as sugestões de Sarmanho eram transformadas em peça de programa de governo: afirmava-se que o governo devia defender a sustentação dos altos preços do café, do algodão e do cacau (sem excluir uma política de ampliação da exportação de outros produtos), porque se esta já seria uma política aconselhável em tempos normais, "justifica-se de maneira especial, na presente conjuntura, em que o suprimento de artigos essenciais à manutenção da atividade nacional deve ser procurado em qualquer país que seja capaz de atendê-lo" (G. VARGAS, MENSAGEM..., 1951, P. 90). Pois, em meio à sua escassez generalizada, o aumento dos preços dos bens essenciais importados podia até inverter o resultado

$15 \mathrm{Na}$ verdade, o debate na imprensa sobre a necessidade de estocagem de produtos essenciais já era intenso desde o início da campanha eleitoral (coincidindo aproximadamente com o início das hostilidades na Coréia): ver Jornal "O Globo" (08/08/1950), Jornal "O Jornal" (01 e 10/09), Jornal "Correio da Manhã" (08/09) e Jornal "O Economista" (26/09). Diante da possibilidade de deflagração de um conflito mundial, a política que Sarmanho recomendava a Vargas era a de se antecipar aos acontecimentos. Tratava-se de acelerar o ritmo de formação de estoques de insumos essenciais em detrimento de importações não-essenciais, antes da imposição de cotas para exportação de produtos estadunidenses ou, antes disto, de aumento ainda maior das cotações internacionais, que acompanharia a escassez de suprimentos trazida por nova mobilização de guerra. Como forma de financiamento externo das compras ("sempre que as nossas disponibilidades cambiais não permitirem o pagamento com nossos próprios recursos"), deveria apelar-se ao BIRD, ao Eximbank e à formação de um pool de bancos privados estadunidenses. E, internamente, deveria ampliar-se o crédito seletivo para conferir recursos tanto a iniciativas subsidiárias do esforço de estocagem, quanto à aceleração de investimentos voltados a substituir as importações mais caras de produtos manufaturados, pela importação de insumos ou matériasprimas a serem manufaturadas internamente, apressando a construção de novos silos, refinarias de petróleo, destilarias de álcool etc. (GV 50.09.03). 
favorável das contas externas, devendo orientar uma rápida política de estocagem antes que isto acontecesse:

"As perspectivas são, aliás, de uma nova inversão da balança comercial externa, e, mesmo, do balanço de pagamento, à falta de disponibilidades exportáveis de bens essenciais ao Brasil, nos mercados tradicionalmente fornecedores. Sob esse aspecto, o grande saldo verificado na balança comercial, em 1950, constitui mau presságio para o ano em curso. Cumpre, portanto, incrementar as aquisições externas de bens essenciais, até mesmo com a conseqüente acumulação de estoques daqueles que se vão tornando escassos, assegurando-se ao país, por outro lado, através de acordos internacionais, o suprimento regular das mercadorias estrangeiras imprescindíveis à nossa economia, em face da conjuntura mundial" (idem, pp. 90-91).

É significativo que, na Mensagem de 1951, a menção à ameaça de guerra fosse acompanhada pela advertência de que, antes de assumir, Vargas havia encomendado estudos que indicavam as políticas emergenciais diante do cenário ameaçador. Vargas acreditava que a adaptação ao contexto internacional não podia ser lenta $\mathrm{e}$ gradual, mas tomada em caráter de urgência:

"Os recentes acontecimentos começam a refletir-se no comércio mundial... Os preparativos de defesa das nações vêm alterar as condições de oferta e procura nos mercados mundiais. É de presumir que, num prazo relativamente curto, a situação do balanço de pagamentos do país tenda a inverter-se. Antes mesmo de iniciar o mandato, atribui importância primordial ao estudo dos problemas e das medidas relacionadas com as perspectivas internacionais, para, tomadas em tempo oportuno as providências cabiveis, como já o vêm sendo, compensar os impactos negativos das novas condições sobre a economia nacional" (idem, p. 95).

A política de importações estava em meio a um dilema: quanto mais demorasse a constituir estoques essenciais, o risco era maior em vista do possível de corte da oferta mundial; mas se a concessão de licenças para a formação de estoques fosse rápida demais frente às disponibilidades de divisas, o risco de ficar sem divisas para realizar compras futuramente também existiria. Entre ficar sem divisas por acelerar as compras, ou economizar divisas e ser incapaz de usá-las posteriormente, a opção do governo era pelo primeiro dos dois riscos: a prioridade era impedir que, pela falta de insumos, "tudo ou quase tudo fique paralisado, em uma regressão de 
meio século", nos termos da campanha eleitoral. Mas para prevenir de forma mais duradoura ambos os riscos, Vargas propunha acelerar o processo de substituição de importações em simultâneo à constituição dos estoques de bens intermediários, conseguindo recursos externos que ajudassem a financiá-lo:

"No plano interno, além das providências monetárias e fiscais... promover uma politica de estocagem de produtos essenciais: ampliar a capacidade de armazenagem; apressar a conclusão dos empreendimentos de relevante interesse para a economia do país, dependentes de financiamentos externos, obtendo para esse fim as prioridades para as importações indispensáveis" (p. 96).

Embarcar em um processo acelerado de substituição de importações que modificasse a própria estrutura produtiva era muito arriscado naquela circunstância, pois as importações necessárias para os investimentos concorreriam com as exigências de divisas para formar estoques de bens intermediários que fizessem funcionar a estrutura produtiva já existente. Mas o risco estava sendo calculado, exigindo a rápida conclusão de acordos internacionais para suprimento de bens essenciais e financiamento de projetos que viabilizassem a produção interna. De fato, a proposta de fomentar investimentos nas indústrias de base era reforçada, naquela conjuntura internacional, pela necessidade de evitar o impacto desfavorável da interrupção do fornecimento de insumos básicos sobre a estrutura produtiva já existente, até então concentrada em bens de consumo:

"A dificuldade de aquisição de matérias primas e maquinaria estrangeiras, em virtude da situação nacional, é um desses empecilhos que tende a agravar-se. Às restrições adotadas pelos países fornecedores que já se fazem sentir no Brasil, principalmente nas indústrias que consomem metais não-ferrosos, produtos quimicos essenciais, ferro e aço, folha-de-flandres, ao mesmo tempo em que se acentuam as dificuldades para obtenção de equipamentos. Como medida destinada a evitar maiores entraves à expansão das indústrias nacionais de bens de consumo, cumpre fomentar a criação das indústrias de base destinadas a garantir suprimentos regulares..." (idem, p. 129).

Em suma, a ameaça de guerra exigia acelerar o processo de adaptação do Brasil a choques externos (guerras, crises cambiais) que lhe impossibilitavam, regularmente, suprir-se de importações essenciais, induzindo obter suprimentos básicos através de projetos locais. De todo modo, frente à grande instabilidade internacional, caberia à CEXIM ajustar-se rapidamente às mudanças de conjuntura, mas sem se afastar 
dos princípios definidos no sentido de selecionar prioridades inequívocas no uso das divisas. Ou seja, no sentido de evitar que a importação de bens de consumo concorresse com as importações de bens intermediários e de capital fixo:

"A natureza extremamente dinâmica dos problemas econômicos exige que a atuação da referida Carteira se ajuste às exigências das conjunturas que lhe cumpre atender, mas sem que se afaste ela de suas diretrizes essenciais. Tenho, entretanto, a lamentar que ultimamente, interpretando com otimismo os efeitos dos melhores preços alcançados pelo café e outros produtos, a Carteira tivesse afrouxado a aplicação dos critérios que deveriam orientá-la, invertendo, em aplicações não essenciais ou simplesmente especulativas, disponibilidades exigidas por setores básicos...Louvando-se na gravidade da situação internacional, a execução do controle permitiu importações maciças de produtos não-essenciais, sob os mais variados pretextos, inclusive o de estocagem." (idem, p. 96).

A defesa de uma política seletiva que limitasse a importação de bens de consumo não essenciais ou com similar nacional não era, entretanto, uma decisão induzida apenas, naquela circunstância internacional emergencial, pela necessidade de economizar divisas para propiciar as importações mais essenciais de bens intermediários e de capital sem similar no país. Como nas propostas da campanha presidencial, a política cambial seletiva também era justificada pela necessidade de resguardar o crescimento das indústrias nacionais de bens de consumo, protegendo-as da competição internacional - assim como fizeram os países industrializados no fomento de suas indústrias nascentes. ${ }^{16}$

Houve grande continuidade entre preocupações da campanha presidencial e propostas da Mensagem de 1951, em todos os temas acima abordados. O programa de governo era claro: orientar investimentos na direção da produção de insumos básicos e bens de capital, superando as restrições ao desenvolvimento econômico, o que também era considerado uma condição para a conciliação de classes sociais. Para

16 "O impacto sofrido por essa indústria (de bens de consumo), em 1947, por motivo das importações indiscriminadas e em massa de manufaturas já fabricadas no País, não arrefeceu o ânimo dos industriais que, não obstante a concorrência externa, mantiveram o ritmo de produção ... e empreenderam a renovação e ampliação de equipamentos, grandemente desgastados pelo esforço de guerra. Contudo, a experiência demonstrou, então, que a indústria nacional não pode prescindir de uma sadia política de comércio exterior, tendente a pôr as empresas instaladas para produção de artigos essenciais a coberto de surpresas resultantes de liberalidades excessivas em relação à concorrência externa. A falta de política aduaneira e, mais que isso, a situação cambial exigem a instituição daquela política, que deverá ser seguida pelo menos enquanto não se achar devidamente consolidada a posição industrial do país em face das nações industrialmente desenvolvidas. Preconizando tal orientação adotamos tão só a diretriz seguida por todas essas nações, durante o seu desenvolvimento" (idem, p. 128). 
isto, o Estado devia realizar ou induzir investimentos para superar pontos de estrangulamento, com planos setoriais bem definidos. ${ }^{17}$ A coerência entre o programa de investimentos reestruturantes e as políticas macroeconômicas era óbvia: estas deveriam contar com a expansão do crédito para fomentar a produção e combater a inflação, com política cambial seletiva para fomentar a substituição de importações e política fiscal que evitasse déficits, mas também aumentasse recursos para investimentos públicos nos ramos básicos. ${ }^{18}$

Este programa não era ortodoxo (como sugerido por VIANNA, 1987), nem meramente reativo ao agravamento das restrições externas gerado pela abertura liberal do governo Dutra e, depois, por mais uma rodada de substituição de importações concentrada no setor de bens de consumo. Na verdade, a Mensagem de 1951 adaptava, a um novo contexto, o programa de intervenção desenvolvimentista já delineado durante a guerra, mas barrado pelo avanço liberal. Agora, a justificativa ideológica desenvolvimentista para a intervenção estatal era exatamente a de que era mais conforme a "tendências manifestadas" no processo de substituição de importações no Brasil, ao contrário das ilusões liberais quanto à suficiência de capitais externos e exportações tradicionais:

"O desenvolvimento econômico requer crescentes importações de bens de produção e, de vez que os rendimentos se elevam, também maiores volumes de importação de bens de consumo. Mas a ampliação das importações supõe um incremento da procura inter-

17 O programa acelerado de substituição de importações deveria envolver investimentos na siderúrgica, inclusos os de aços especiais (p.120 e segs.); em produtos químicos básicos, como aço sulfúrico, álcalis, barrilha e soda cáustica (pp.124 e segs.); na produção de motores (p. 127); de equipamentos de transporte e comunicação (pp. 151 e segs.), além de investimentos que superassem os estrangulamentos de transportes e comunicações (pp. 143 e segs.), e no fornecimento de energia elétrica a partir de usinas hidrelétricas (pp. 156 e segs.). Ainda não havia qualquer referência à indústria de materiais elétricos, mas Vargas conferia uma especial ênfase à realização de projetos de investimento voltados ao refino interno de petróleo. O objetivo básico era economizar divisas com a substituição das importações de petróleo já refinado por importações de petróleo bruto a ser manufaturado internamente, em conjunto com o fomento à construção nacional de navios petroleiros (para reduzir custos de frete e ameaças de interrupção de fornecimento por escassez de praça marítima) e de novos silos para estocagem (idem, pp. 162-6). A mesma lógica seria válida para fomentar a produção interna de carvão (pp. 167-8).

18 A Mensagem de 1951 reproduzia, às vezes textualmente, propostas de campanha nas críticas a Dutra (pp. 13-4, 81-3, 94, 96-7); na importância do crédito para fomentar a produção e combater a inflação (pp. 12, 83-4, 86-7); no papel da política cambial seletiva para a substituição de importações, em conjunto com a política de crédito (pp. 84, 89-92, 95-6, 128); na importância do equilíbrio orçamentário para combater a inflação e financiar empreendimentos públicos (pp. $12,67-8,77,81-3,185-6$ ); na necessidade de orientar investimentos para produção de insumos básicos e bens de capital, com ênfase na intervenção do Estado (pp. 91-2, 122, 129, 133, 143, 151, 156-9, 162, 168); no papel da cooperação internacional para complementar a carência interna de capitais (pp. 187-9); no papel do crescimento como condição de conciliação de classes (pp. 12-3, 222-4); na urgência do programa com a Guerra da Coréia, exigindo estocagem de bens essenciais - e aceleração da substituição de importações apoiada em financiamento interno e externo (pp. 90-1, 95-7). 
nacional para nossos produtos de exportação ao lado da entrada de capitais estrangeiros. Nossas exportações, entretanto, não se têm expandido numa taxa equivalente à demanda de importações $e$, de outro, não têm sido ponderáveis, nem estáveis, os influxos de capitais. Em conseqüência, tende a balança de contas do país a ser cronicamente desequilibrada, coartando o progresso econômico... Nessas condições, a economia nacional, através de lento e descontínuo processo de adaptação, vem sofrendo uma transformação estrutural, que consiste essencialmente na substituição de importações pela produção doméstica e na diversificação das exportações. Esse processo, que se iniciou pela substituição das importações das manufaturas destinadas ao consumo, se prolonga na fase mais recente pelo crescimento de produção interna de bens de capital, antes importados...Um dos objetivos fundamentais da política econômica do governo deve residir na criação das condições que facilitem o referido processo de adaptação, em conformidade com as tendências manifestadas, como a solução naturalmente indicada para assegurar não só o desenvolvimento econômico como o equilíbrio das relações internacionais. A correção do desequilíbrio permanente do balanço de pagamentos importa em defender as iniciativas nacionais, para garantia da expansão da produção substitutiva de importações, sempre que economicamente viável; em expandir as receitas de exportação e em assegurar um influxo estável de capitais estrangeiros" (idem, pp. 91-2).

Os programas da Mensagem de 1951 não ficaram no papel, mas orientaram a condução do governo. Isto talvez seja mais claro nos projetos de investimentos priorizados pela alocação de recursos fiscais e financeiros, embora não tenham sido coordenados por alguma agência central de planejamento, a não ser pelo próprio presidente e sua assessoria, de modo pouco formalizado. Isto foi enfatizado por vários membros da assessoria econômica do presidente, o corpo burocrático informal que o assessorava na redação de programas e no acompanhamento das políticas: a crer no depoimento de Jesus Soares Pereira (membro original da Assessoria e seu segundo coordenador), vários dos programas parciais elaborados pela assessoria até 1954, e não foram poucos, seguiram as diretrizes básicas (ainda gerais e vagas) do que chamou de "Mensagem Programática" de 1951 (J. S. PEREIRA, 1976, pp. 89 e segs). ${ }^{19}$

19 Cleantho de Paiva Leite, outro importante assessor direto de Vargas, foi ainda mais longe ao afirmar que "...essa integração de vários projetos isolados é a característica principal, dominante, do segundo governo Vargas. Em vez de projetos isolados, você tem, no segundo governo, esse quadro, 


\section{A Frustração do Programa Econômico: Incoerência ou Problemas de Financiamento?}

\section{É claro que a formulação de um programa não garante sua execução com correspon-} dência integral, nem harmonia política na equipe, mas o presidente nomeou uma equipe cujas tarefas foram estipuladas programaticamente, arbitrou conflitos internos, buscou fiscalizar a execução para corrigir desvios, por exemplo, despachando com ministros em conjunto com assessores que acompanhavam o andamento de projetos. A fiscalização da política monetária e cambial foi operada por meio de relatórios enviados ao presidente, que dirimia conflitos e, eventualmente, recorria a assessores e mudanças de equipe para corrigir eventuais desvios. Na política de crédito, Ricardo Jafet foi indicado para o Banco do Brasil com a missão explícita de expandir o volume e rebaixar o custo do crédito, gozando de proteção presidencial contra a tentativa de enquadramento do banco ao Ministério da Fazenda, de onde Horácio Lafer pretendia implementar uma política de crédito menos expansiva, com apoio da SUMOC. Além de prestigiar Jafet publicamente ao elogiar a política de expansão do crédito pelo BB, Vargas abortou a tentativa de Lafer de submeter o banco à Diretoria-Executiva da SUMOC ao substituir o diretor Walther Moreira Salles por José Soares Maciel Fo ${ }^{20}$

esses parâmetros, dentro dos quais vão se inscrevendo os problemas prioritários do país" (apud V. ROCHA et alli, 1986, p. 251). Para Rômulo de Almeida, embora houvesse unidade de diretriz entre os projetos parciais elaborados, vinculá-los a um plano de metas era visto pelo presidente como politicamente oneroso e até tecnicamente ineficaz, mas envolvia o risco de dificultar a coordenação pela ausência de um organismo formal de centralização. "Agora, não se falava em plano, em planejamento não se falava, por uma razão: havia primeiro um bombardeio contra essa idéia de plano... ainda continuava no ar aquela polêmica do Gudin contra o Simonsen e o grande bombardeio de Gudin contra o livro de Von Mises e de Hayek e tal, e então havia um certo receio. Por outro lado o presidente, como era um homem muito ligado a uma idéia de Estado atuante e tinha uma grande resistência contra ele - a maioria no Congresso, suspicácias internacionais, alguns elementos do setor privado e tudo mais -, então ele teve muita preocupação de evitar que ostensivamente se adotasse esse nome, pelo menos na fase inicial." (R. ALMEIDA, 1980, p. 7 e 10). Depois que vários programas parciais amadureceram, porém, o risco em admitir a existência de um planejamento central implícito aos projetos foi assumido, particularmente na Mensagem de 1953, sujeito à ressalva, porém, de que o plano não nascera pronto, mas vinha sendo atualizado constantemente: "Como acentuei no discurso do segundo aniversário da atual gestão, os programas que o governo tem lançado, ou cujos estudos estão em andamento, pela sua coerência e unidade fundamental, apresentam, em conjunto, o característico de um plano de governo. Não era, entretanto, possível retardar o início dos programas parciais - tão desprovido estava e ainda está o país de recursos básicos e tão carente de técnicos — até que se elaborasse um plano global. A integração formal e informal dos programas parciais de energia, transportes, agricultura, indústrias de base, de obras sociais e de política monetária, na unidade de um plano, com as retificações recíprocas que se impuserem, é tarefa que já determinei e está sendo realizada em coordenação com os órgãos próprios. Para elaboração definitiva do plano e de sua permanente atualização, torna-se cada vez mais notória a necessidade da criação de um Conselho de Planejamento e Coordenação contando com serviços técnicos suficientemente equipados"

(O GOVERNO TRABALHISTA DO BRASIL, vol. III, p. 277). Algo similar à agência proposta (O CONSELHO DE DESENVOLVIMENTO ECONÔMICO) foi criado no governo JK.

20 Cabe lembrar que a crítica que Lafer fazia ao BB não vinha de fontes ortodoxas, mas do argumento de que o crédito devia ser mais seletivo para apoiar imobilizações de capital fixo e o pleno emprego, evitando inflação de estoques mercantis, loteamento de terras e imóveis urbanos. Sobre 
A política cambial executada por Lafer e pela SUMOC também cumpriu os desígnios presidenciais, destinando reservas cambiais para financiar importações de bens de capital e insumos, que aumentaram muito em 1951-2, antes que uma nova crise cambial forçasse sua desaceleração. A crise resultou de restrições comerciais e financeiras tradicionais, agravadas por movimentos de preços e quantidades comerciadas vinculadas à Guerra da Coréia. ${ }^{21}$

De todo modo, antes da crise, recursos cambiais e financeiros baratos oferecidos pelo Banco do Brasil não eram suficientes para financiar investimentos pesados nos ramos básicos, cujos requisitos de financiamento ultrapassavam o horizonte financeiro das firmas locais e nos quais a disponibilidade de tecnologias materializadas em bens de capital importados era limitada. Em outras palavras, a utilização da política cambial como instrumento de política industrial se limitava a incentivar demandas de diversificação industrial passíveis de serem atendidas mediante bens de capital acessíveis no mercado internacional, e cujos requisitos de financiamento e escala (ou mesmo de risco) estivessem ao alcance de decisões de diversificação do capital local que não exigissem mecanismos mais avançados de centralização de capitais. Para o projeto de superar a industrialização restringida, porém, era necessário criar fundos financeiros internos e mobilizar recursos em moeda externa em escala muito superior àquela passível de acumulação pelas firmas locais, mesmo quando estas firmas compensassem parcialmente suas disponibilidades de capital com crédito e câmbio baratos, ou seja, com políticas monetárias e cambiais que atendessem aos desígnios de Vargas.

O problema do programa de Vargas não era a incoerência, mas o financiamento, para o que o par crédito/câmbio seletivo e barato era instrumental, mas insuficiente. O maior óbice tampouco era a obtenção de recursos locais, a despeito da resistência

a heterodoxia de Lafer e o fracasso de sua tentativa de controlar o BB, por não contar com o apoio do presidente, ver Bastos (2005). Maciel Filho era o principal colaborador dos discursos econômicos de Vargas (e o único a ajudar na "Carta Testamento"), sendo escalado para fiscalizar a política creditícia e cambial, antes de acumular a Diretoria-Executiva da SUMOC e a Superintendência do BNDE. Em um relatório decisivo, dizia: "Quer a Superintendência da Moeda e do Crédito, quer o Ministro da Fazenda, em todos os documentos enviados a V. Exa. só tinham o objetivo de insistir para um conjunto de medidas que restringisse o crédito interno em cruzeiros, acusando o Banco do Brasil de uma expansão de crédito e culpando-o da inflação que se vinha acentuando. As restrições de crédito determinam encarecimento do dinheiro e, portanto, aumento de custo da produção...O que nos parece mais sábio é a) iniciar a organização do controle das posições estratégicas; b) iniciar a organização dos quadros de confiança; c) iniciar lentamente pressões suaves para correção dos fenômenos...; d) reorganizar o quadro das pessoas de confiança" (GV $52.07 .14 / 2)$.

21 O relatório de Maciel sobre a política cambial (GV 52.07.14/2) equivocou-se ao acusar SUMOC e CEXIM de desperdiçar reservas com importações de bens de consumo: estas foram, na imensa maioria, feitas sem que o critério de seletividade no uso das reservas fosse desrespeitado, ou seja, através de operações vinculadas a exportações de produtos "gravosos" ou através de convênios comerciais de compensação bilateral. Sobre a crise cambial, ver Tavares (1963) e Malan et alli (1977). 
conservadora no Congresso Nacional. A mobilização de recursos locais foi destinada à assessoria econômica e à Fazenda. A assessoria elaborou projetos que envolviam novas agências e fundos fiscais vinculados. Ao invés de esperar por reformas financeira, tributária e administrativa gerais, preferiu contornar obstáculos políticos por meio de reformas incrementais no sistema tributário e administrativo. Como "braço" de Vargas na formulação de novos programas, a atuação da assessoria foi pródiga. $^{22}$

À Fazenda coube, em um primeiro momento, assegurar o equilíbrio orçamentário através de aumento da arrecadação e racionalização do gasto, priorizando investimentos; e elaborar um plano financeiro que deveria permitir, em um segundo momento, ampliar a capacidade de produção nos ramos básicos sem prejudicar o equilíbrio orçamentário. O Plano Nacional de Reaparelhamento Econômico (ou Plano Lafer) contaria com o empréstimo compulsório de adicional sobre o Imposto de Renda, assim como recursos do Banco Mundial e do Eximbank (imprescindíveis para os gastos em moeda externa), constituindo o Fundo de Reaparelhamento Econômico (FRE). Os recursos seriam geridos pelo novo Banco Nacional de Desenvolvimento Econômico (BNDE), que financiaria projetos prioritários elaborados pela Comissão Mista Brasil-Estados Unidos (CMBEU).

Horácio Lafer foi o responsável pela tramitação do projeto do BNDE junto ao Congresso Nacional, enquanto o Ministério das Relações Exteriores cuidou da negociação dos recursos externos dos projetos da CMBEU, seguindo instruções claras de Vargas. O objetivo era obter recursos nos termos do Ponto IV, ou seja, do compromisso do presidente Truman de prover assistência a países pobres. O governo Dutra já requisitara a formação de uma comissão bilateral desde abril de 1949, mas a troca de notas diplomáticas que formalizaria o início dos estudos para a formação de uma comissão mista só se realizaria em dezembro de 1950 — depois de já ser conhecida a vitória de Vargas nas eleições de outubro e, sobretudo, de já haver sido convocada pelos estadunidenses a IV Reunião de Consulta dos Chanceleres Americanos, visando obter apoio continental para a mobilização militar na Coréia. O sinal para uma barganha era claro, e ele foi rapidamente entendido pelo novo governo brasileiro.

22 Foram propostas da Assessoria, por exemplo, Petrobrás, Fundo Nacional de Eletrificação, Eletrobrás, Plano Nacional do Carvão, Comissão de Desenvolvimento Industrial (e seu Plano Geral de Industrialização), Subcomissão de Jeeps, Tratores, Caminhões e Automóveis, CAPES, Carteira de Colonização do Banco do Brasil, Instituto Nacional de Imigração, Comissão Nacional de Política Agrária, Banco do Nordeste do Brasil, Plano Nacional do Babaçu, Companhia Nacional de Seguros Agrícolas e Conselho Nacional de Administração de Empréstimos Rurais (ver D'ARAÚJO, 1982, p. 135). Para análise das transformações do aparelho de Estado no segundo governo, ver Draibe (1980, cap. 3); para uma listagem sucinta dos órgãos criados, sob influência da Assessoria Econômica ou não, ver Fonseca (1987, p. 366). 
Desde o início das gestões bilaterais, era claro ao governo Vargas que o Ponto IV criara uma excelente oportunidade. O objetivo do presidente era trocar o alinhamento político-militar por colaboração econômico-financeira, seguindo o padrão que dera certo nas negociações que levaram ao financiamento da CSN em 1942 e buscando assegurar, agora, não só suprimentos essenciais em caso de emergência, como recursos para levar adiante os projetos de superação dos estrangulamentos na infraestrutura de transportes e energia identificados na campanha presidencial. ${ }^{23}$ Isto era confidenciado por João Neves a Oswaldo Aranha, em carta datada de 09/01/51:

\begin{abstract}
"Devemos cooperar - e havemos de cooperar com os Estados Unidos -, mas a cooperação deve ser recíproca, conseguindo nós que as utilidades a serem alcançadas no estrangeiro se convertam em utilidades indispensáveis ao Brasil, em bens de produção ou semelhantes...se entregarmos, embora bem vendidos, nossos minerais estratégicos, é justo que também tenhamos fábricas de seus produtos para nossa defesa que é, também, a defesa dos Estados Unidos" (OA 51.01.09).
\end{abstract}

Também era claro ao governo que o objetivo estratégico estadunidense, ao iniciar nova rodada de "cooperação pan-americana", era assegurar o fornecimento de minerais estratégicos no Brasil e, se possível, contar com o apoio de uma nova força expedicionária brasileira na Coréia (ver Jornal "O Globo", 19/01/1951; GV 51.01.01/1; OA 51.01.09). Como Vargas resistiu atender à solicitação de envio de tropas à Coréia, a posse de materiais estratégicos foi o principal trunfo utilizado pelos negociadores brasileiros para assegurar a colaboração externa, desde o início das negociações bilaterais. ${ }^{24}$

23 "A carência de capitais nacionais, impossível de suprir-se sem sacrifícios dos níveis de vida, reclama um crescente influxo adicional de capitais estrangeiros...Em face da experiência do após-guerra na finança mundial, devemos esperar mais da cooperação técnica e financeira de caráter público. Até porque a maior aplicação de capitais privados pressupõe a existência de condições que só podem ser criadas mediante inversões públicas em setores básicos... Nossas fontes de capitais públicos são hoje o governo norte-americano, através do Eximbank, e os organismos internacionais, criados em Bretton Woods... o Brasil está incluído entre as áreas da economia mundial que se devem beneficiar com a ajuda técnica e financeira através do denominado Ponto IV..." (VARGAS, 1951, pp. 187-8).

24 De fato, Vargas chegaria a afirmar, em entrevista a O Globo (19/01/1951), que a exportação de areias monazíticas seria a grande arma brasileira na Reunião de Chanceleres, dali a três meses. Isto não deixaria de ser enfatizado em despacho do vice-cônsul estadunidense no Rio de Janeiro ao Departamento de Estado: NA-M1489: 832.00/1-2251. No memorando enviado ao embaixador estadunidense em janeiro de 1951, em que estipulava os termos da barganha, Vargas tampouco escondia que: "A boa vontade do governo brasileiro de contribuir com as matérias-primas nacionais para a economia de emergência dos Estados Unidos deve encontrar sua contrapartida na boa vontade do governo norte-americano de conceder prioridades de fabricação e créditos bancários a termo médio e longo, para a imediata execução de um programa racional de industrialização e de obras públicas, ao qual serão consagrados os principais esforços da administração brasileira" (GV 51.01.04/2). 
As pressões surtiram efeito, pelo menos até que os trunfos brasileiros desaparecessem. Ao receber o memorando de Vargas, o Sub-Secretário de Estado sugeriu ao Secretário Acheson que enviasse memorando ao presidente Truman, em que se afirmava que o memorando de Vargas criava uma nova urgência nas relações bilaterais e era "um dos mais importantes documentos das relações Estados Unidos-Brasil nos anos recentes" (NA-M1489: 832.00/1-2551). Em julho de 1951, após intensas negociações, a CMBEU foi constituída a partir de um compromisso informal estadunidense de assegurar, junto ao Banco Mundial e ao Eximbank, pelo menos US\$ 300 milhões para financiar os projetos aprovados pela Comissão Mista. Estes recursos eram imprescindíveis para contornar a escassez de reservas cambiais para importar bens de capital e serviços de engenharia estrangeiros.

A dura negociação por financiamento externo mostra que Vargas não era "xenófobo", pois precisava superar tanto as restrições cambiais quanto as resistências políticas internas à centralização de recursos pelo Estado. A propósito, a necessidade de contrapartida financeira em moeda local para os recursos externos foi usada por Lafer, em sua negociação com o Congresso Nacional, para contornar resistências políticas à aprovação do Fundo de Reaparelhamento Econômico e do BNDE, sob pena de perder os recursos externos. Vargas também não era "entreguista": se não rejeitava a associação financeira, tampouco aceitava qualquer associação. De todo modo, precisava de trunfos para barganhar por termos de associação mais favoráveis aos investimentos nos ramos básicos e ao financiamento das urgentes necessidades cambiais, agravadas com a crise cambial de 1952.

Não foi a falta de coordenação da política econômica, mas duas restrições estruturais, que puseram a perder o programa econômico do governo. Primeiro a própria crise cambial, não apenas porque pôs em risco importações imprescindíveis de bens de produção, mas porque seu encarecimento animou a inflação e o conflito distributivo, reforçando tensões políticas internas que vinham de longa data (cuja análise foge ao escopo desse artigo). Segundo, porque o trunfo usado para obter concessões financeiras foi perdido graças à descoberta de fontes de monazita nos EUA. Isto tornou o plano de desenvolvimento vulnerável ao governo Eisenhower que, a partir de 1953, abandonava o Ponto IV e procurava influenciar mais diretamente a definição das fronteiras entre filiais estrangeiras e empresas estatais no modelo de desenvolvimento de países periféricos, tolerando e mesmo financiando uma maior intervenção estatal apenas onde as necessidades de combate do comunismo exigissem (RABE, 1988). Sob o argumento de que os países em desenvolvimento deveriam se esforçar, com vantagens, para criar um ambiente favorável à atração de capitais estrangeiros, ao invés de esperarem ajuda financiada pelo contribuinte americano, o novo governo dos EUA denunciou o acordo de cooperação financeira 
que instituíra a CMBEU, e pôs a perder o esquema de financiamento do projeto de desenvolvimento do segundo governo Vargas.

\section{Conclusão}

O artigo procurou mostrar que Vargas tinha um programa econômico coerente para seu segundo governo. Ao fazê-lo, o artigo contradiz interpretações que enfatizaram a incoerência econômica do governo. Embora, como afirmado por autores como Skidmore ou D’Araújo, a existência de solicitações políticas incoerentes tenha caracterizado as tensas relações de Vargas com os partidos políticos, a corporação militar e os sindicatos patronais e trabalhistas (cuja análise foge ao escopo deste artigo), incoerências graves não parecem caracterizar o programa econômico, a nomeação da equipe e a própria execução econômica. Em um contexto histórico que não dispunha do controle autônomo das fontes de recursos necessárias para implementar seus projetos, Vargas não foi incoerente na tentativa de complementar agentes e recursos locais e estrangeiros.

Mas sua dependência de decisões estrangeiras de financiamento criava uma vulnerabilidade central. De fato, a crise do projeto econômico do segundo governo esteve muito associada a sua falta de controle sobre decisões externas de financiamento, no contexto das negociações com os Estados Unidos, e sobre preços de commodities exportadas pelo Brasil. O projeto econômico não fracassou por ser ortodoxo ou incoerente: sem dispor do controle autônomo das fontes de recursos para implementar seus programas de investimento, fracassou por ser vulnerável a um centro decisório estrangeiro que se mostrou contrário ao projeto nacional-desenvolvimentista proposto e, em particular, à definição de fronteiras entre filiais estrangeiras e empresas estatais inerentes à proposta varguista.

\section{ARQUIVOS CONSULTADOS}

ARQUIVOS DO CENTRO DE PESQUISA E DOCUMENTAÇÃO DE HISTÓRIA CONTEMPORÂNEA DO BRASIL (CPDOC-FGV): GV: Getúlio Vargas; OA: Oswaldo Aranha; SC: Souza Costa.

U. S. NATIONAL ARCHIVES (NA) - SÉRIE M -1487 e M - 1489.

\section{Referências}

ALMEIDA, R. Depoimento a M. C. D’Araújo e R. Roels Jr. (março de 1980). CPDOC-FGV (reg. E-109), 1980. 
BASTOS, P. P. Z. O presidente desiludido: a campanha liberal e o pêndulo de política econômica no governo Dutra (1942-1948). In: História Econômica e História das Empresas, volume VII.1, jun., 2004.

____. Desenvolvimentismo incoerente? In: Revista Economia, vol. 6, n.3 (selecta), dez., 2005.

-_- A construção do nacional-desenvolvimentismo de Getúlio Vargas e a dinâmica de interação entre Estado e mercado nos setores de base. In: Revista Economia, Vol. 7, num. 4 (selecta), dez., 2006.

BIELSCHOWSKY, R. (1985) Pensamento econômico brasileiro: o ciclo ideológico do desenvolvimentismo. Rio de Janeiro: IPEA/INPES, 1988.

CAMPOS, R. O. (1984). A lanterna na popa: memórias. Rio de Janeiro: Topbooks, 1994.

CARONE, E. (1976) O Estado Novo (1937-1945). São Paulo, Editora DIFEL, 1976.

A Quarta República. São Paulo, Editora DIFEL, 1980.

CORSI, F. L. (1997). Estado Novo: Política externa e projeto nacional. São Paulo, UNESP/FAPESP, 2000.

D'ARAUJO, M. C. O segundo governo Vargas (1951-54). Rio de Janeiro, Editora Zahar, 1982.

DRAIBE, S. M. Rumos e metamorfoses. Rio, Paz e Terra, 1985.

FONSECA, P. D. (1987). Vargas: o capitalismo em construção. São Paulo, Brasiliense, 1989.

- (2004) Gênese e Precursores do Desenvolvimentismo no Brasil. Pesquisa \& Debate, São Paulo, v. 15, nº 2.

. (2005) Vargas no Contexto da Primeira República. In: SZMERECSÁNYI, T.; GRANZIERA, R. (Org.). Getúlio Vargas \& a Economia Contemporânea. 2 ed. São Paulo: Editora HUCITEC, 2005, p. 171-192.

IANNI, O. O colapso do populismo no Brasil. Rio de Janeiro: Civilização Brasileira, 1968.

LAGO, P. C. A SUMOC como embrião do Banco Central, 1945/1964. Rio de Janeiro: PUC, 1982.

LESSA \& FIORI. E Houve uma política nacional-populista? In: Anais do XII Encontro de Economia, 1984

MALAN et alli. Política econômica externa e industrialização no Brasil (1939/52). Rio: IPEA/INPES, 1977.

PEREIRA, J. S. Petróleo, energia elétrica, siderurgia. Rio de Janeiro: Paz e Terra, 1975. 
RABE, S. G. Eisenhower and Latin America: the foreign policy of anticommunism. Chapel Hill; London: Univ. of North Carolina, 1988.

SARETTA, F. Política Econômica Brasileira: 1946-1951. São Paulo: Cultura Acadêmica, 2000.

SKIDMORE, T. (1967). Brasil: de Getúlio Vargas a Castelo Branco. Rio de Janeiro: Paz e Terra, 1982.

SODRÉ, N., W. Formação histórica do Brasil. 4.ed.São Paulo: Editora Brasiliense, 1967. 1997.

. Capitalismo e revolução burguesa no Brasil. 2.ed. Rio de Janeiro: Grafia,

TAVARES, M. C. (1963). Auge e declínio do processo de substituição de importações no Brasil. In: Da substituição de importações ao capitalismo financeiro. Rio de Janeiro: Zahar, 1972.

. (1974). Acumulação de capital e industrialização no Brasil. Ed. UNICAMP, Campinas, 1998.

VARGAS, G. (1946-1948). A política trabalhista no Brasil. São Paulo: J. Olympio, 1950.

. (1950). A Campanha Presidencial. São Paulo: J. Olympio, 1951.

. (1951-4). Mensagem ao Congresso Nacional (1951-1954). Rio de Janeiro: Imprensa Nacional.

. (1950-4). O governo trabalhista no Brasil, vols. I-IV. Rio de Janeiro: José Olympio (1952-1969).

VIANNA, S. B. (1985). A política econômica no segundo governo Vargas. Rio de Janeiro: BNDES, 1987. 